\title{
The diet of introduced brook trout (Salvelinus fontinalis; Mitchill, 1814) in an alpine area and a literature review on its feeding ecology
}

\author{
Rocco TIBERTI,,${ }^{1,2 *}$ Stefano BRIGHENTI, ${ }^{1}$ Claudia CANEDOLI, ${ }^{3}$ Rocco IACOBUZIO,${ }^{4}$ Giulia PASQUINI, ${ }^{5}$ \\ Matteo ROLLA ${ }^{6}$
}

\begin{abstract}
${ }^{1}$ Alpine Wildlife Research Centre, Gran Paradiso National Park, Degioz 11, 11010 Valsavarenche, Aosta, Italy; ${ }^{2}$ DSTA, Dipartimento di Scienze della Terra e dell'Ambiente, Università degli Studi di Pavia, Via Ferrata 9, 27100 Pavia, Italy; ${ }^{3}$ DISAT, Dipartimento di Scienze dell'Ambiente e del Territorio e di Scienze della Terra, Università degli Studi Milano-Bicocca, Piazza della Scienza 1, 20126 Milano, Italy; ${ }^{4} \mathrm{DBS}$, Dipartimento di Bioscienze, Università degli Studi di Milano, Via Celoria 26, 20133 Milano, Italy; ${ }^{5} \mathrm{BiGeA}$, Dipartimento di Scienze Biologiche, Geologiche e Ambientali, Università di Bologna, P.zza di Porta San Donato 1, 40126 Bologna, Italy; ${ }^{6}$ Department of BioSciences, Swansea University, Singleton Park SA2 8PP, Swansea, UK
\end{abstract}

*Corresponding author: rocco.tiberti@gmail.com

\begin{abstract}
Introduced fish are a major threat for high altitude aquatic habitats and Salvelinus fontinalis have been widely used throughout the Alps for stocking lakes and rivers. Understanding its feeding ecology is a basic, but essential tool for interpreting its impact. To assess which factors determine the diet of $\mathrm{S}$. fontinalis we analyzed more than 500 stomachs from several introduced populations from the Gran Paradiso National Park (GPNP, Western Italian Alps) and we measured the availability of several prey groups (zooplankton, aquatic invertebrates, terrestrial invertebrates). We complemented the study with a short, but exhaustive literature review on the S. fontinalis feeding ecology. In general the food composition reflected the availability of prey-confirming that $\mathrm{S}$. fontinalis is an opportunistic predator-and was influenced by habitat type (stream vs lake), fish size, and seasonality. The obtained results were discussed in the light of the existing literature on the feeding ecology and ecological impact of S. fontinalis. Large benthonic insects account for a substantial part of the diet of stream dwelling brook trout, while they are almost absent both in the diet and in the prey species pool of lake-dwelling brook trout, probably reflecting a stronger ecological impact in the lakes.
\end{abstract}

Key words: Stomach content; alpine rivers; alpine lakes; prey availability; Gran Paradiso National Park; LIFE+ Bioaquae.

Received: October 2015. Accepted: April 2016.

\section{INTRODUCTION}

In mountain regions, a substantial part of river basins lies upstream of natural barriers to fish colonization and was thus naturally fishless (Bahls, 1992; Adams, 2001). All habitats upstream of these barriers provide refugia for peculiar aquatic species and communities, often lacking anti-predatory adaptations and thus vulnerable to fish invasions (Bellati et al., 2014). Unlike other clades, where introduction pathways are often unintentional, the widespread presence of fish in mountain regions is commonly linked to deliberate manipulations for recreational angling (García-Berthou et al., 2005), producing an artificial range expansion of native species, or the establishment of new species from different eco-regions. Fish stocking in headwater basins provides source populations facilitating the invasion of downstream habitats, including otherwise inaccessible refugia (Adams, 2001). Introduced fish have profoundly altered the ecology of high altitude aquatic habitats such as streams (Bechara $e t$ al., 1993) and lakes (Knapp et al., 2001) and are considered a major threat for their conservation.

The Gran Paradiso National Park (GPNP) is a large protected area of the western Italian Alps and one of the few
Alpine protected areas where fishing is largely prohibited, in accordance with the most recent scientific findings, that clearly show that fishing bans are the most effective measure to stem the spread of invasive fish in mountain areas (Mirò and Ventura, 2013; Mirò and Ventura, 2015). Nevertheless, in the 1960s, before fishing ban was established in the 1970s, some populations of Salvelinus fontinalis have been introduced in a number of naturally headwater lakes, which served as a source for the colonization of the downstream habitats. S. fontinalis established many reproductive populations in some large portions of the GPNP hydrographic system. This salmonid, native of North America, is considered one of the most impacting fish in alpine aquatic habitats and, unfortunately, it has been one of the most utilized alien species for stocking alpine lakes and rivers (Savini et al., 2010).

To understand the ecological consequences of $S$. fontinalis introduction and to try to recover the invaded ecosystems, the GPNP started a long term research campaign (since 2006) and an eradication project from four headwater lakes (LIFE+ Bioaquae, Biodiversity Improvement of Aquatic Alpine Ecosystems, www.bioaquae.eu). 
In this context the understanding of the feeding ecology of $S$. fontinalis is a basic, essential tool to interpret its impact in alpine areas. This study aims at understanding which are the factors determining the diet of lake and stream dwelling $S$. fontinalis from the populations of the GPNP. Our results will be discussed in the light of the existing literature on the feeding behavior of $S$. fontinalis and in relation to its ecological impact in the study area (Tiberti and von Hardenberg, 2012; Magnea et al., 2013; Tiberti et al., 2014a) and may be useful to anyone interested in the invasion ecology of this species in the alpine environment. To this purpose we complemented our study with a short review of the existing literature on the feeding ecology of $S$. fontinalis. Specific aims of the study are: i) to understand how the diet of $S$. fontinalis changes depending on the habitat (lakes vs streams), the fish size, and seasonality; ii) to compare the diet of Salvelinus fonti- nalis with the availability of prey measured in the different studied habitats; and iii) to review the existing literature on the feeding ecology of $S$. fontinalis.

\section{METHODS}

\section{Study area and period}

The Gran Paradiso National Park is a protected area in the western Italian Alps (Fig. 1), showing a large altitudinal extension (between 800 and $4061 \mathrm{~m}$ ) and a typical alpine climate. The sampling sites for $S$. fontinalis stomach contents (Fig. 1) and prey availability are comprised between 1875 and $2757 \mathrm{~m}$ asl, above or at the local timberline. A short description of each sampling site is provided in Tab. 1. S. fontinalis was the only fish species in all the sampling sites, with the exception of a single site (Orco-3; Tab. 1), where brown trout Salmo trutta and rainbow trout $\mathrm{On}$ -

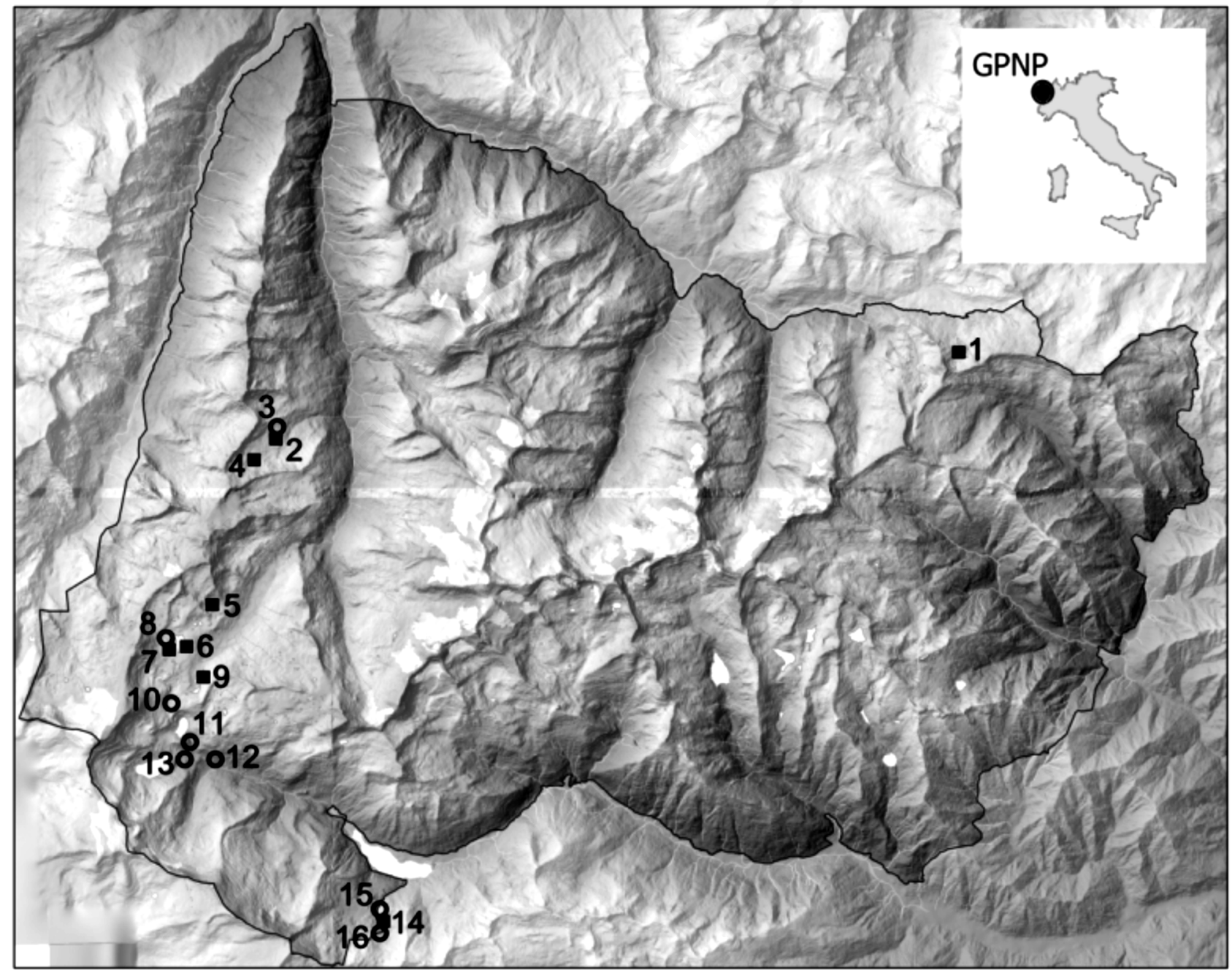

Fig. 1. Map of the Gran Paradiso National Park (GPNP), its position in Italy, and samplings sites (from 1 to 16, see Tab. 1) for Salvelinus fontinalis stomach contents. Black line, Gran Paradiso National Park border; black squares, lacustrine sampling sites; empty circles, riverine sampling sites. 
corhynchus mykiss were also present. Field work was carried out between 2006 and 2014 from June to November.

\section{Literature review}

Web of Science (by Thomson Reuters) and Google Scholar databases searches were conducted to retrieve articles, technical and scientific reports, and theses related to the feeding ecology of $S$. fontinalis. Search terms included all the possible combinations among the terms 'brook trout/Salvelinus fontinalis' and the terms 'diet/feeding ecology/food/impact'. The reference lists of each document were reviewed in detail to find additional useful references.

\section{Fish capture and permissions}

Between 2006 and 2014 we captured more than $20,000 \mathrm{~S}$. fontinalis using a variety of systems including nets (gillnets, trammel nets, and multimesh gillnets), electrofishing (with a ELT62 II 160 GI backpack equipment) and fishing ropes. A total of 821 captures were made in 2006-2012 during a long term monitoring program (Tiberti et al., 2014c), while the remaining captures were made in 2013-2014 within the fish eradication project LIFE+ Bioaquae. Permissions for fishing activities have been issued by the GPNP (protocol number $1798 / 1013 / \mathrm{BB}$ ) with the favorable opinion of ISPRA (Istituto Superiore per la Protezione e Ricerca Ambientale, protocol number 0017655 - 29/04/2013).

\section{Stomach contents analysis}

A total of 506 stomachs were dissected for prey presence/absence analysis, a subsample of 232 for prey items counting, and a subsample of 304 (from fish larger than 15 $\mathrm{cm}$ ) for the analysis of prey biovolumes (Tab. 2). The fish maximum length was converted into seven size classes en-

Tab. 1. Sampling sites of Salvelinus fontinalis stomach contents in the Gran Paradiso National Park (data from Tiberti et al., 2010). Coordinates of stream sampling sites refer to their start point, at the lower altitude.

\begin{tabular}{|c|c|c|c|c|c|c|}
\hline Sampling site & Watershed & Habitat type & UTM 32 T coordinates & Altitude & $\mathbf{N}$ & Short description \\
\hline 1 Miserino & Ourtier & Lake & $380686-5048871$ & 2666 & 1 & Area: 4.22 ha. Maximum depth: $9.9 \mathrm{~m}$ \\
\hline 2 Djouan & Savaranche & Lake & $357850-5046521$ & 2515 & 96 & Area: 1.83 ha. Maximum depth: $3.0 \mathrm{~m}$ \\
\hline 3 Djouan outlet & Savaranche & Stream & $357910-5046598$ & 2511 & 1 & Length of the sampled stream stretch: $40 \mathrm{~m}$ \\
\hline 4 Nero & Savaranche & Lake & $357071-5045892$ & 2671 & 25 & Area: 1.71. Maximum depth: $6.0 \mathrm{~m}$ \\
\hline 5 Leynir & Savaranche & Lake & $355624-5041016$ & 2747 & 96 & Area: 4.47 ha. Maximum depth: $22.1 \mathrm{~m}$ \\
\hline 6 Rosset & Orco & Lake & $354540-5039773$ & 2703 & 19 & Area: 16.86 ha. Maximum depth: $46.9 \mathrm{~m}$ \\
\hline 7 Leità & Orco & Lake & $354052-5039506$ & 2701 & 29 & Area: 6.22 ha. Maximum depth: $11.0 \mathrm{~m}$ \\
\hline 8 Leità inlet & Orco & Stream & $354087-5039747$ & 2701 & 2 & Length of the sampled stream stretch: $50 \mathrm{~m}$ \\
\hline 9 Nivolet inferiore & Savaranche & Lake & $355120-5038595$ & 2526 & 15 & Area: 8.24 ha. Maximum depth: $14 \mathrm{~m}$ \\
\hline 10 Orco-1 & Orco & Stream & $354137-5037693$ & 2504 & 5 & Length of the sampled stream stretch: $125 \mathrm{~m}$ \\
\hline 11 Orco-2 & Orco & Stream & $354885-5036331$ & 2150 & 1 & Length of the sampled stream stretch: $105 \mathrm{~m}$ \\
\hline 12 Orco-3 & Orco & Stream & $355637-5035584$ & 1875 & 4 & Length of the sampled stream stretch: $75 \mathrm{~m}$ \\
\hline 13 Orco-4 & Orco & Stream & $354528-5035937$ & 2160 & 7 & Length of the sampled stream stretch: $70 \mathrm{~m}$ \\
\hline 14 Dres & Orco & Lake & $361018-5030347$ & 2087 & 143 & Area: 2.71 ha. Maximum depth: $7.4 \mathrm{~m}$ \\
\hline 15 Dres outlet & Orco & Stream & $360907-5030392$ & 2057 & 5 & Length of the sampled stream stretch: $279 \mathrm{~m}$ \\
\hline 16 Dres inlet & Orco & Stream & $360999-5030268$ & 2087 & 58 & Length of the sampled stream stretch: $120 \mathrm{~m}$ \\
\hline
\end{tabular}

$N$, number of analyzed stomachs.

Tab. 2. Number of specimens of Salvelinus fontinalis examined for stomach content analysis divided by sampling habitat, type of analysis, and total length (size classes). Data from 506 specimens sampled in lacustrine and riverine habitats in the Gran Paradiso National Park.

\begin{tabular}{|c|c|c|c|c|c|c|c|c|c|}
\hline Habitat & Analysis & $\begin{array}{l}\text { Class } 1 \\
0-5 \mathrm{~cm}\end{array}$ & $\begin{array}{l}\text { Class } 2 \\
5-10 \mathrm{~cm}\end{array}$ & $\begin{array}{l}\text { Class } 3 \\
10-15 \mathrm{~cm}\end{array}$ & $\begin{array}{c}\text { Class } 4 \\
15-20 \mathrm{~cm}\end{array}$ & $\begin{array}{l}\text { Class } 5 \\
20-25 \mathrm{~cm}\end{array}$ & $\begin{array}{l}\text { Class } 6 \\
25-30 \mathrm{~cm}\end{array}$ & $\begin{array}{l}\text { Class } 7 \\
>30 \mathrm{~cm}\end{array}$ & $\mathbf{N}$ \\
\hline Lake & Presence/absence analysis & 49 & 42 & 30 & 34 & 167 & 78 & 23 & 423 \\
\hline Lake & Prey counts & 44 & 23 & 25 & 27 & 35 & 19 & 9 & 182 \\
\hline Lake & Biovolume measurements & - & - & - & 23 & 157 & 69 & 18 & 267 \\
\hline Stream & Presence/absence analysis & 4 & 34 & 5 & 15 & 9 & 16 & 1 & 83 \\
\hline Stream & Prey counts & 4 & 5 & 5 & 13 & 9 & 14 & 0 & 50 \\
\hline Stream & Biovolume measurements & - & - & - & 14 & 8 & 15 & 0 & 37 \\
\hline
\end{tabular}


compassing the values from 0 to $\geq 30 \mathrm{~cm}$ at five centimeters intervals. Analyzed stomachs belong to all the present size classes. Stomachs were preserved in $70 \%$ ethanol.

Stomachs from larger fish were dissected in a Petri dish under a stereomicroscope. Larger prey were sorted until all the prey items identifiable under the stereoscope maximum magnification had been recorded or separated for prey counting and biovolume measurement. What remained in the dish was checked for the presence of microscopic preys (e.g., zooplankton), and, if necessary, we proceeded with a microscopic analysis using a closed counting chamber for zooplankton under a binocular dissecting microscope at 40X (Olympus CH-BI45-3). Stomachs from smaller fish (approximately $<10 \mathrm{~cm}$ ) were dissected under the stereomicroscope and directly analyzed using the closed counting chamber. Biovolumes were measured by gently pressing the prey items belonging to each prey group in a graduated cylinder. Prey groups with very small biovolumes $(<0.05 \mathrm{~mL})$ were approximated to zero in the subsequent data analyses.

Prey were divided into six macro-groups based on their ecological niche (Tab. 3), so that several prey taxa with complex life history were separated in different groups (i.e., terrestrial $v s$ aquatic life stages). Within macro-groups we used different taxonomic levels (Tab. 3). Fragmented or partially digested items were recognized using body parts resistant to digestion (e.g., cephalic capsule) or recorded as non-identified prey and grouped in a separate category.

\section{Prey availability}

Prey availability was determined using different sampling methods depending on the sampled habitat and taxa. All the results concerning prey availability have been qualitatively presented as frequency of occurrence in the samples.

Pelagic zooplankton: 146 samples were collected at all the lacustrine sampling sites (Fig. 1) in June-October 2006-2014. Samples were collected at the deepest point of each lake by taking vertical tows from the bottom to the surface with a conical plankton net $(40 \mathrm{~cm}$ diameter, $48 \mu \mathrm{m}$ mesh). Samples were preserved in $70 \%$ ethanol and sorted to species/genus.

Lacustrine macroinvertebrates: 64 samples were collected at sampling sites 2, 4, 5, 6, 7, 9, and 14 (Fig. 1) in June-September 2006-2014. Samples were collected from the littoral zone by conducting 30 standard sweeps with a rectangular dip net $(25 \mathrm{~cm}$ width, $20 \mathrm{~cm}$ height; mesh 0.5 $\mathrm{mm})$. A standard sweep consisted of a 1-m sweep in one direction followed immediately by a $1-\mathrm{m}$ sweep across the same area in the opposite direction (Knapp et al., 2001). Samples were preserved in $70 \%$ ethanol and sorted to class/order.

Riverine macroinvertebrates: Twelve samples were collected at sampling sites 3, 15, and 16 (Fig. 1) between
2013 and 2014. Samples were collected with a standard Surber sampler (mouth width $32 \mathrm{~cm}$; mesh $0.5 \mathrm{~mm}$ ), sampling a total surface of $1 \mathrm{~m}^{2}$ including all the available aquatic habitats following Buffagnini and Erba (2007). Samples were preserved in $70 \%$ ethanol and sorted to class/order.

Terrestrial invertebrates around the lakes: Pitfall traps (50 $\mathrm{mm}$ inner diameter, $70 \mathrm{~mm}$ deep, $1 / 3$ filled with a 1:1 solution of water and vinegar) were used to sample ground-dwelling arthropods (Cole et al., 1992) around the lacustrine sampling sites 2, 4, 5, 6, 7, 9, and 14 (Fig. 1) in August-September 2009. The traps were protected with flat stones and were placed at 1, 10 and 50 meters from the coastline, along four transects placed at the four cardinal points (12 traps per lake). Each set of pitfall was left for 9-13 days. 68 samples were obtained (16 traps were flooded or disturbed by cattle). Samples were preserved in $70 \%$ ethanol and sorted to class/order.

Terrestrial arthropods falling into the lake: 65 nonempty samples of sinking terrestrial invertebrates were collected at sampling sites 2, 4, 5, 6, 7, 9, and 14 (Fig. 1) in June-September 2013-2014 using sinking traps. Sinking traps consist of a cone of fine plastic mesh (diameter $56 \mathrm{~cm}$; mesh size $1 \mathrm{~mm}$ ) with their mouth facing upwards. Eight traps per lake were repeatedly placed below the water surface and were left for 5-14 days in correspondence with randomly generated points along the $2 \mathrm{~m}$ isobaths. Random points were obtained using the runifpointOnLines function of the spatstat package implemented in the R 3.1.1 statistical software (R Core Team, 2011). Samples were preserved in $70 \%$ ethanol and sorted to class/order.

\section{Data presentation and analysis}

For the description of the diet, data are offered on frequency of occurrence of the prey groups $\left(\mathrm{F}_{\mathrm{i}}=\mathrm{N}_{\mathrm{i}} / \mathrm{N} \times 100\right.$, where $\mathrm{N}_{\mathrm{i}}$ is the number of fish with prey $\mathrm{i}$ in their stomach and $\mathrm{N}$ is the total number of analyzed stomachs), relative abundance $\left(\mathrm{Ai}=\mathrm{S}_{\mathrm{i}} / \mathrm{S}_{\mathrm{t}} \times 100\right.$, where $\mathrm{S}_{\mathrm{i}}$ is the sum of the counts of prey $i$ in all the stomachs and $S_{t}$ is the total sum of all the prey items counted), and relative biovolume $\left(\mathrm{B}_{\mathrm{i}}=\mathrm{V}_{\mathrm{i}} / \mathrm{V}_{\mathrm{t}} \times 100\right.$, where $\mathrm{V}_{\mathrm{i}}$ is the sum of the biovolumes of prey $i$ in all the stomachs and $\mathrm{V}_{\mathrm{t}}$ is the total sum of all the measured biovolumes). Sampling adequacy for diet composition was determined by visual inspection of the cumulative prey curves and using Lehner's formula $\mathrm{Q}=1$ $\left(\mathrm{N}_{1} / \mathrm{I}\right)$ (Lehner, 1996), rising from 0 to 1 , where $\mathrm{Q}$ is sampling adequacy, $\mathrm{N}_{1}$ is the number of the food components occurring only once, and I is the total number of the food components. The order of the stomach content analysis was randomized and the cumulative prey curves were represented plotting the cumulative number of prey groups against the cumulative number of stomachs analyzed.

To determine which factors influence the diet of the 
studied S. fontinalis populations and to avoid pseudoreplications due to repeated and unbalanced samplings at the same sites, we used some generalized mixed effects mod- els. An exhaustive summary of how the models were fitted is provided in Tab. 4. When modeling the presence/absence of each prey group, we added the remaining prey

Tab. 3. Diet of Salvelinus fontinalis from alpine lakes and rivers in Gran Paradiso National Park in relation to prey availability.

\begin{tabular}{|c|c|c|c|c|c|c|c|c|c|c|}
\hline \multirow[b]{3}{*}{ Prey groups } & \multicolumn{3}{|c|}{ Lakes } & \multicolumn{3}{|c|}{ Streams } & \multicolumn{3}{|c|}{ Total } & \multirow{3}{*}{$\begin{array}{c}\text { Prey availability } \\
\text { F\% }\end{array}$} \\
\hline & F $\%$ & A $\%$ & B $\%$ & F $\%$ & A $\%$ & B $\%$ & F $\%$ & A $\%$ & B $\%$ & \\
\hline & $\mathrm{N}=423$ & $\mathrm{~N}=182$ & $N=267$ & $\mathbf{N}=\mathbf{8 3}$ & $\mathbf{N}=50$ & $\mathbf{N}=37$ & $\mathrm{~N}=506$ & $\mathbf{N}=232$ & $\mathrm{~N}=304$ & \\
\hline Zooplankton & 17.73 & 21.55 & 0.77 & 3.61 & 0.31 & 0.00 & 15.42 & 20.12 & 0.63 & \\
\hline Copepoda - Eucyclops surrulatus & 1.42 & 0.27 & 0.00 & - & - & - & 1.19 & 0.25 & 0.00 & $41.10^{\mathrm{f}}$ \\
\hline Copepoda - Cyclops gr. abyssorum & 8.75 & 1.88 & 0.00 & - & - & - & 7.31 & 1.75 & 0.00 & $70.55^{\mathrm{f}}$ \\
\hline Copepoda - Arctodiaptomus alpinus & 0.71 & 1.80 & 0.07 & - & - & - & 0.59 & 1.68 & 0.06 & $69.86^{\mathrm{f}}$ \\
\hline Cladocera - Chydorus sp. & 2.36 & 0.12 & 0.00 & - & - & - & 1.98 & 0.11 & 0.00 & $26.71^{\mathrm{f}}$ \\
\hline Cladocera - Alona sp. & 3.55 & 1.44 & 0.00 & - & - & - & 2.96 & 1.35 & 0.00 & $13.70^{\mathrm{f}}$ \\
\hline Cladocera - Acropaerus harpae & 2.36 & 0.11 & 0.00 & - & - & - & 1.98 & 0.10 & 0.00 & $14.38^{\mathrm{f}}$ \\
\hline Cladocera - Scapholeberis mucronata & 0.47 & 0.13 & 0.00 & - & - & - & 0.40 & 0.12 & 0.00 & $0.68^{f}$ \\
\hline Cladocera - Daphnia gr. longispina & 7.09 & 15.74 & 0.70 & 1.20 & 0.00 & 0.00 & 6.13 & 14.69 & 0.57 & $52.1^{\mathrm{f}}$ \\
\hline Ostracoda & 1.18 & 0.06 & 0.00 & 2.41 & 0.31 & 0.00 & 1.38 & 0.07 & 0.00 & $1.37^{\mathrm{f}}$ \\
\hline Rotifera & - & - & - & - & - & - & - & - & - & $99.31^{\mathrm{f}}$ \\
\hline Nectonic invertebrates & 45.39 & 42.88 & 27.23 & 27.71 & 1.76 & 0.32 & 42.49 & 40.06 & 22.99 & \\
\hline Nectonic Coleoptera, i & 0.95 & 0.10 & 0.04 & 1.20 & 0.10 & - & 0.99 & 0.03 & 0.03 & $14.7^{g}-18.8^{h}$ \\
\hline Nectonic Diptera, $\mathrm{p}^{\mathrm{a}}$ & 40.66 & 42.63 & 26.00 & 26.51 & 1.61 & 0.16 & 38.34 & 39.89 & 21.17 & $15.6^{\mathrm{g}}-0.0^{\mathrm{h}}$ \\
\hline Aquatic Heteroptera & 5.44 & 0.10 & 1.19 & 2.41 & 0.05 & 0.16 & 4.94 & 0.10 & 0.99 & $4.7^{\mathrm{g}}-8.3^{\mathrm{h}}$ \\
\hline Isopoda & 0.24 & 0.05 & 0.00 & - & - & - & 0.20 & 0.04 & 0.00 & $0.0^{\mathrm{g}}-0.0^{\mathrm{h}}$ \\
\hline Benthonic invertebrates & 19.62 & 1.07 & 4.96 & 81.93 & 38.28 & 45.97 & 29.84 & 3.6 & 12.61 & \\
\hline Benthonic Coleoptera, 1 and i & 0.71 & 0.00 & 0.00 & 2.40 & 0.05 & 0.16 & 0.99 & 0.01 & 0.03 & $8.8^{\mathrm{g}}-56.3^{\mathrm{h}}$ \\
\hline Plecoptera, 1 & 7.57 & 0.14 & 0.04 & 63.86 & 8.42 & 4.03 & 16.80 & 0.68 & 0.78 & $21.9^{\mathrm{g}}-83.2^{\mathrm{h}}$ \\
\hline Efemeroptera, 1 & 0.47 & 0.02 & 0.00 & 32.53 & 2.51 & 0.97 & 5.73 & 0.17 & 0.18 & $4.7^{\mathrm{g}}-91.7^{\mathrm{h}}$ \\
\hline Tricoptera, 1 & 13.48 & 0.82 & 3.07 & 50.60 & 26.78 & 40.81 & 19.57 & 2.58 & 10.12 & $25.0^{\mathrm{g}}-100.0^{\mathrm{h}}$ \\
\hline Benthonic Diptera, $1^{\mathrm{b}}$ & 0.47 & 0.01 & 0.00 & 9.64 & 0.52 & 0.00 & 1.98 & 0.04 & 0.00 & $0.0^{\mathrm{g}}-83.3^{\mathrm{h}}$ \\
\hline Odonata, 1 & 0.95 & 0.02 & 1.85 & - & - & - & 0.79 & 0.02 & 1.50 & $1.6^{\mathrm{g}}-0.0^{\mathrm{h}}$ \\
\hline Hydracarina & 2.13 & 0.06 & 0.00 & 3.61 & 0.73 & 0.00 & 2.37 & 0.10 & 0.00 & $9.5^{\mathrm{g}}-25.0^{\mathrm{h}}$ \\
\hline Aquatic fossorial invertebrates & 40.43 & 23.15 & 9.22 & 44.58 & 39.74 & 1.45 & 41.11 & 24.04 & 8.77 & \\
\hline Mollusca - Pisidium sp. & 6.15 & 0.13 & 0.22 & - & - & - & 5.14 & 0.12 & 1.18 & $53.1^{\mathrm{g}}-25.0^{\mathrm{h}}$ \\
\hline Fossorial Diptera, $1^{c}$ & 36.64 & 22.87 & 9.00 & 43.37 & 38.49 & 1.29 & 37.75 & 23.70 & 7.56 & $100.0^{\mathrm{g}}-100.0^{\mathrm{h}}$ \\
\hline Oligochaeta & 0.47 & 0.01 & 0.00 & 1.20 & 0.10 & 0.00 & 0.59 & 0.02 & 0.00 & $98.4^{g}-91.7^{\mathrm{h}}$ \\
\hline Nematomorpha & 0.95 & 0.02 & 0.00 & 3.61 & 0.42 & 0.16 & 1.38 & 0.04 & 0.03 & $0.0^{\mathrm{g}}-0.0^{\mathrm{h}}$ \\
\hline Copepoda - Harpacticoida & 2.60 & 0.12 & 0.00 & 3.61 & 0.73 & 0.00 & 2.77 & 0.16 & 0.00 & Not sorted \\
\hline Terrestrial invertebrates & 74.00 & 8.87 & 34.41 & 65.06 & 14.95 & 15.62 & 72.53 & 9.44 & 31.89 & \\
\hline Coleoptera, i & 55.08 & 2.07 & 10.48 & 31.32 & 6.69 & 3.22 & 51.19 & 2.36 & 9.12 & $62.8^{\mathrm{k}}-29.2^{\mathrm{j}}$ \\
\hline Diptera/Imenoptera, i & 60.76 & 6.66 & 22.93 & 63.86 & 7.27 & 9.67 & 61.26 & 6.65 & 20.45 & $88.5^{\mathrm{k}}-70.8^{\mathrm{j}}$ \\
\hline Orthoptera & 1.18 & 0.01 & 0.22 & - & 0.10 & 0.00 & 1.38 & 0.01 & 1.18 & $10.9^{\mathrm{k}}-0.0^{\mathrm{j}}$ \\
\hline Lepidoptera, i and 1 & 0.47 & 0.00 & 0.11 & 1.20 & 0.00 & 0.32 & 0.59 & 0.00 & 0.15 & $9.0^{\mathrm{k}}-0.0^{\mathrm{j}}$ \\
\hline Plecoptera, i & 0.95 & 0.01 & 0.30 & 3.61 & 0.31 & 0.48 & 1.38 & 0.03 & 0.33 & $0.0^{\mathrm{k}}-0.0^{\mathrm{j}}$ \\
\hline Tricoptera, i & 0.24 & 0.02 & 0.00 & 8.43 & 0.16 & 1.45 & 1.58 & 0.06 & 0.27 & $0.0^{\mathrm{k}}-1.5^{\mathrm{j}}$ \\
\hline Hemiptera & 4.26 & 0.09 & 0.30 & 3.61 & 0.16 & 0.16 & 4.15 & 0.09 & 0.27 & $0.0^{\mathrm{k}}-0.0^{\mathrm{j}}$ \\
\hline Collembola & 0.24 & 0.00 & 0.00 & - & - & - & 0.20 & 0.00 & 0.00 & $16.7^{\mathrm{k}}-0.0^{\mathrm{j}}$ \\
\hline Aranea & 1.42 & 0.01 & 0.07 & 4.82 & 0.26 & 0.32 & 1.98 & 0.03 & 0.12 & $70.5^{\mathrm{k}}-4.6^{\mathrm{j}}$ \\
\hline Miriapoda & 0.24 & 0.00 & 0.00 & 0.00 & 0.00 & 0.00 & 0.20 & 0.00 & 0.00 & $6.4^{\mathrm{k}}-0.0^{\mathrm{j}}$ \\
\hline Terrestrial Acarina & - & - & - & - & - & - & - & - & - & $32.1^{\mathrm{k}}-0.0^{\mathrm{j}}$ \\
\hline Vertebrates & 2.36 & 0.03 & 22.03 & 10.84 & 0.83 & 36.35 & 3.76 & 0.07 & 24.73 & \\
\hline Salvelinus fontinalis ${ }^{\mathrm{d}}$ & 1.89 & 0.02 & 7.96 & 2.41 & 0.10 & 0.71 & 1.98 & 0.02 & 6.63 & - \\
\hline Rana temporaria ${ }^{\mathrm{e}}$ & 0.47 & 0.01 & 14.07 & 8.43 & 0.73 & 35.64 & 1.79 & 0.05 & 18.10 & - \\
\hline Undetermined rests & 14.66 & 2.52 & 1.37 & 6.02 & 3.40 & 0.16 & 13.24 & 2.56 & 1.14 & \\
\hline
\end{tabular}

$F \%$, frequency of occurrence of the group in the analyzed stomachs or samples; $A \%$, percent abundance of prey group compared to the sum of all the counted prey items; $B \%$, percent biovolume of prey group compared to the sum of all the measured biovolumes; I, imaginal stage; $l$, larvae; $p$, pupae.

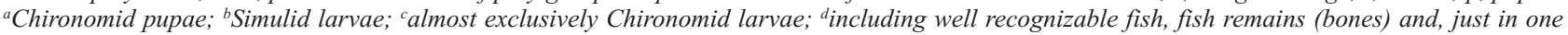
case, eggs; ' including adult and juvenile frogs and frogs remains (bones); 'based on 146 zooplankton samples collected in lacustrine sampling sites 1 , 2, 4, 5, 6, 7, 9, and 14 between 2006 and 2014; ' based on 64 samples for benthic invertebrates collected in lacustrine sampling sites 2, 4, 5, 6, 7, 9, and 14 between 2006 and 2014; ' hased on 12 samples for benthic invertebrates collected in riverine sampling sites 3, 15, and 16 between 2013 and 2014; ${ }^{k}$ based on 68 samples for terrestrial invertebrates collected around the lacustrine sampling sites 2, 4, 5, 6, 7, 9, and 14 in 2009; ${ }^{j}$ based on 65 non-empty samples for terrestrial invertebrates falling into the water collected in lacustrine sampling sites 2, 4, 5, 6, 7, 9, and 14 between 2013 and 2014. 
groups as covariates (to test for the presence of associations/exclusions between prey groups) and we used the MuMIn package (Bartoń, 2011; Grueber et al., 2011) to select the best fitting models $(\triangle A I C C<4)$ among the models including all possible combinations of the fixed covariates. For the Prey groups models we report the 95\% confidence intervals of the averaged parameter estimates and the relative importance of the covariates provided by the function model.avg of MuMIn.

\section{RESULTS}

\section{Literature review}

Our literature review include 126 publications (articles, theses and reports) from different areas of North America (102 documents), Europe (5 documents), South America (4 documents) and New Zeland (1 document), encompassing more than one century of research (19032015). A large part of the studies were carried out in the wild, in riverine, lacustrine, and estuarine habitats, within (75) or outside (34) the native range of S. fontinalis. Only a few studies include mesocosm or laboratory experiments (13). In Tab. 5 we provide all the references and we summarize the main objectives of the reviewed literature.

\section{Description of the diet and prey availability}

A descriptive summary of the diet of $S$. fontinalis in lakes and streams is provided in Tab. 3. We identified 36 prey groups in the diet of $S$. fontinalis (36 in lakes and 25 in streams) that were clumped into six macro-groups according to their ecology. Sampling adequacy index (Q) was satisfactory for both lacustrine samples $(\mathrm{Q}=0.94)$ and riverine samples $(\mathrm{Q}=0.84)$, as also demonstrated by the asympthotic behavior of the prey cumulative curves (Fig. 2). The mean number $\pm \mathrm{SD}$ of prey belonging to different prey groups in the stomach contents was $2.59 \pm 2.12$ (range $0-13 ; \mathrm{N}=423$ ) in lakes and 3.84 \pm 2.10 (range $0-10 ; \mathrm{N}=83$ ) in rivers; the mean number of prey items per stomach was $160.37 \pm 364.95$ (range $0-3223 ; \mathrm{N}=183$ ) and $41.68 \pm 66.00$ in rivers (range 0 -
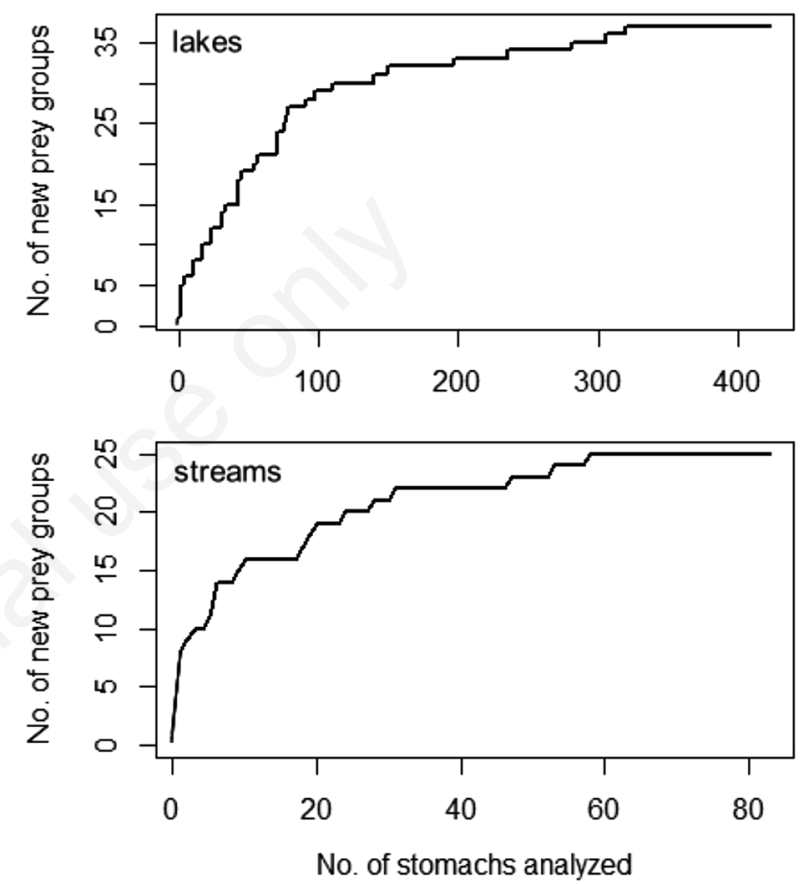

Fig. 2. Diet of Salvelinus fontinalis from alpine lakes and rivers: cumulative prey curves.

Tab. 4. Generalized linear mixed models to determine the factors influencing the diet of $S$. fontinalis from alpine lakes and rivers in the Gran Paradiso National Park: summary of their structures.

\begin{tabular}{lll} 
Models & Models features & \\
Prey number & Dependent variables & $\begin{array}{l}\text { Prey richness (number of prey groups per stomach) and abundance (total number of prey } \\
\text { items per stomach) }\end{array}$ \\
& Fixed effects & Habitat + size + day \\
Random effects & Sampling site + year \\
Error distribution & Poisson \\
Biovolume & Dependent variable & Log transformed of the total biovolume of stomach contents +1 \\
& Fixed effects & Habitat + size + day \\
Random effects & Sampling site + year \\
Error distribution & Gaussian \\
\hline Prey groups & Dependent variables & Presence/absence of each prey group \\
& Fixed effects & Habitat + size + day + remaining prey groups presence/absence \\
& Random effects & Sampling site + year \\
& Error distribution & Binomial \\
\hline
\end{tabular}

Habitat, stream vs lake; day, standardized Julian date as days gone by June 15 of the year of sampling; size, fish size classes from 1 to 7; prey groups, binomial covariates indicating the presence/absence of each prey group (zooplankton, nektonic invertebrates, benthonic invertebrates, aquatic fossorial invertebrates, terrestrial insects, and vertebrates); year, year of sampling; sampling site, random factor including eight riverine and eight lacustrine sampling sites. 
Tab. 5. List of the reviewed literature on S. fontinalis feeding behavior with details on the habitat type (including experimental laboratory and mesocosm artificial habitats). Literature is offered in chronological order.

\begin{tabular}{|c|c|c|c|c|c|}
\hline Reference & Habitat & Region & Diet & Native & Objectives \\
\hline Needham, 1903 & River & Pennsylvania, USA & $\mathrm{Y}$ & $\mathrm{Y}$ & Describing the diet of $S$. fontinalis \\
\hline Juday, 1907a, 1907b & Lake & Colorado, USA & Y & $\mathrm{N}$ & Describing the diet of $S$. fontinalis \\
\hline Morgulis, 1918 & Laboratory & - & - & - & $\begin{array}{l}\text { Determining the food consumption of } \\
\text { S. fontinalis }\end{array}$ \\
\hline Clemens et al., 1924 & Lake & Ontario, CA & Y & Y & $\begin{array}{l}\text { Describing the diet of the fish inhabiting lake } \\
\text { Nipigon }\end{array}$ \\
\hline Embody and Gordon, 1924 & River & USA & Y & Y & $\begin{array}{l}\text { Comparing the diet of wild and captive } S \text {. } \\
\text { fontinalis to enhance food quality in captivity }\end{array}$ \\
\hline Greeley, 1927 & - & Massachusetts, USA & $\mathrm{Y}$ & Y & $\begin{array}{l}\text { Describing the diet of several fish species } \\
\text { including } S \text {. fontinalis }\end{array}$ \\
\hline Greeley, 1928 & - & New York State, USA & Y & Y & $\begin{array}{l}\text { Describing the diet of several fish species } \\
\text { including } S \text {. fontinalis }\end{array}$ \\
\hline Hildebrand and Towers, 1927 & Lake & Utah, USA & Y & $\mathrm{N}$ & $\begin{array}{l}\text { Describing the diet of several fish species } \\
\text { including } S \text {. fontinalis }\end{array}$ \\
\hline Leonard, 1927 & Lake & Québek, CA & Y & $\mathrm{Y}$ & $\begin{array}{l}\text { Describing the diet of several fish species } \\
\text { including } S \text {. fontinalis }\end{array}$ \\
\hline Clemens, 1928 & River & New York State, USA & $\mathrm{Y}$ & Y & Describing the diet of $S$. fontinalis \\
\hline Needham, 1928 & River & - & Y & Y & $\begin{array}{l}\text { Determining the food consumption of } \\
\text { S. fontinalis }\end{array}$ \\
\hline Titcomb et al., 1928 & Laboratory & - & - & - & $\begin{array}{l}\text { Assessing the nutritional requirements and } \\
\text { grow rates in } S \text {. fontinalis }\end{array}$ \\
\hline Metzelaar, 1929 & Lake and river & Michigan USA & $\mathrm{Y}$ & $\mathrm{Y}$ & Describing the diet of the salmonids in Michigan \\
\hline Harkness and Ricker, 1929 & Lake and River & Ontario, CA & Y & $\mathrm{Y}$ & Describing the diet of $S$. fontinalis \\
\hline Detwiler, 1930 & Laboratory & - & - & - & Testing S. fontinalis optimal feeding in captivity \\
\hline Needham, 1930 & River & New York State, USA & $\mathrm{Y}$ & Y & $\begin{array}{l}\text { Describing the seasonal variation in the diet of } \\
\text { S. fontinalis }\end{array}$ \\
\hline Rimsky-Korsakoff, 1930 & - & Vermont, USA & Y & Y & $\begin{array}{l}\text { Describing the diet of several fish species } \\
\text { including } S \text {. fontinalis }\end{array}$ \\
\hline White, 1930 & River & Prince Edward Is., CA & Y & Y & Describing the diet of $S$. fontinalis \\
\hline Ricker, 1930, & Lake and River & Ontario, $\mathrm{CA}$ & $\mathrm{Y}$ & $\mathrm{Y}$ & Describing the diet of $S$. fontinalis \\
\hline Sibley and Rimsky, 1931 & River & Québek, CA & $\mathrm{Y}$ & Y & Describing the biology and diet of $S$. fontinalis \\
\hline Ricker, 1932 & Lake and River & Ontario, CA & $\mathrm{Y}$ & $\mathrm{Y}$ & Describing the biology of $S$. fontinalis \\
\hline Lord, 1933 & River & Vermont, USA & Y & Y & Describing the winter diet of $S$. fontinalis \\
\hline White, 1940 & Sea & Nova Scotia, CA & Y & Y & $\begin{array}{l}\text { Describing the biology of anadromous } S \text {. } \\
\text { fontinalis }\end{array}$ \\
\hline Leonard, 1941, 1942 & River & Michigan, USA & $\mathrm{Y}$ & $\mathrm{Y}$ & Describing the winter diet of $S$. fontinalis \\
\hline White, 1940 & Sea & Nova Scotia, CA & Y & Y & $\begin{array}{l}\text { Describing the biology of anadromous } \\
\text { S. fontinalis }\end{array}$ \\
\hline Wiseman, 1951 & - & - & - & - & Describing the diet of $S$. fontinalis \\
\hline Benson, 1954 & River & Michigan, USA & Y & Y & $\begin{array}{l}\text { Describing the seasonal variation in the diet of } \\
\text { S. fontinalis }\end{array}$ \\
\hline Baldwin, 1957 & Laboratory & - & - & - & $\begin{array}{l}\text { Temperature effects on S. fontinalis food } \\
\text { consumption }\end{array}$ \\
\hline Allen and Claussen, 1960 & Beaver pond & Wyoming, USA & $\mathrm{Y}$ & $\mathrm{N}$ & Describing the diet of $S$. fontinalis \\
\hline Tebo and Hassler, 1963 & River & North Carolina, USA & $\mathrm{Y}$ & $\mathrm{Y}$ & Describing the diet of $S$. fontinalis \\
\hline Reed and Bear, 1966 & River & Colorado, USA & $\mathrm{Y}$ & $\mathrm{N}$ & Describing the diet of $S$. fontinalis \\
\hline Lackey, 1969 & Lake & Maine, USA & $\mathrm{Y}$ & Y & $\begin{array}{l}\text { Describing the diet of several fish species } \\
\text { including } S \text {. fontinalis }\end{array}$ \\
\hline Nyman, 1970 & River & Newfoundland, CA & Y & $\mathrm{Y}$ & $\begin{array}{l}\text { Describing the ecological interaction between } \\
\text { Salmo trutta and S. fontinalis }\end{array}$ \\
\hline Swift, 1970 & Lake & California, USA & Y & $\mathrm{N}$ & $\begin{array}{l}\text { Describing the diet of } S \text {. fontinalis and the } \\
\text { calorimetric content of each prey group }\end{array}$ \\
\hline Bryan and Larkin, 1972 & River, pond & CA & Y & $\mathrm{N}$ & $\begin{array}{l}\text { Studying the food specialization at an individual } \\
\text { level }\end{array}$ \\
\hline Griffith, 1974 & River & Idaho, USA & Y & $\mathrm{N}$ & $\begin{array}{l}\text { Comparing resource partitioning between } \\
\text { S. fontinalis and Salmo trutta }\end{array}$ \\
\hline
\end{tabular}

To be continued on next page 
Tab. 5. Continued from previous page.

\begin{tabular}{|c|c|c|c|c|c|}
\hline Reference & Habitat & Region & Diet & Native & Objectives \\
\hline Miller, 1974 & River & Wisconsin, USA & Y & $\mathrm{Y}$ & Describing the diet of S. fontinalis fry \\
\hline Wurtsbaugh et al., 1975 & Lake & California, USA & Y & $\mathrm{N}$ & $\begin{array}{l}\text { Describing the differences in the diet and } \\
\text { distribution of young S. fontinalis and } \\
\text { Oncorhynchus mykiss }\end{array}$ \\
\hline Flick, 1977 & Lake & $\mathrm{CA}$ & Y & Y & $\begin{array}{l}\text { Describing the ecology of S. fontinalis in some } \\
\text { Canadian Lakes }\end{array}$ \\
\hline Allan, 1978a & River & Colorado, USA & Y & $\mathrm{N}$ & $\begin{array}{l}\text { Comparing the diet of } S \text {. fontinalis and Salmo } \\
\text { trutta in relation to prey availability and daytime }\end{array}$ \\
\hline Allan, 1978b & River & Colorado, USA & Y & $\mathrm{N}$ & $\begin{array}{l}\text { Testing the existence of antipredatory defenses } \\
\text { in drifting macroinvertebrates }\end{array}$ \\
\hline Strogen, 1979 & River & Michigan, USA & Y & $\mathrm{Y}$ & Describing the diet of $S$. fontinalis \\
\hline Johnston, 1980 & River & Prince Edward Is., CA & Y & $\mathrm{Y}$ & Describing the diet of $S$. fontinalis \\
\hline Dutil and Power, 1980 & Estuarine areas, Sea & Québek, CA & Y & Y & $\begin{array}{l}\text { Describing the biology of anadromous } \\
\text { S. fontinalis }\end{array}$ \\
\hline Allan, 1981 & River & Colorado, USA & Y & $\mathrm{N}$ & $\begin{array}{l}\text { Assessing the determinants (daytime, fish size, } \\
\text { prey availability) of } S \text {. fontinalis diet }\end{array}$ \\
\hline Williams, 1981 & River & Québek, CA & Y & Y & Determining the diet of $S$. fontinalis fry \\
\hline Helfrich et al., 1982 & River & North Carolina, USA & $\mathrm{N}$ & Y & $\begin{array}{l}\text { Studying the agonistic interaction of } S \text {. } \\
\text { fontinalis with Oncorhynchus mykiss }\end{array}$ \\
\hline Magnan and FitzGerald, 1982 & Lake & Québek, CA & Y & $\mathrm{Y}$ & $\begin{array}{l}\text { Describing the diet of } S \text {. fontinalis in simpatry } \\
\text { with Semotilus atromaculatus }\end{array}$ \\
\hline Gaudreault et al., 1982 & Estaurine areas, sea & Cnada & $\mathrm{Y}$ & $\mathrm{Y}$ & Describing the diet of anadromous $S$. fontinalis \\
\hline O’Connell, 1982 & River & Canada & Y & Y & $\begin{array}{l}\text { Describing the biology of anadromous } S \text {. } \\
\text { fontinalis }\end{array}$ \\
\hline Dawidowicz and Gliwicz, 1983 & Lake & Tatra Mts., Poland & $\mathrm{Y}$ & $\mathrm{N}$ & Describing the diet of $S$. fontinalis \\
\hline Magnan and FitzGerald, 1984 & Laboratory & - & - & - & $\begin{array}{l}\text { Describing the dietary shift in } S \text {. fontinalis in } \\
\text { the presence of competitors }\end{array}$ \\
\hline Fausch, 1984 & Laboratory & - & - & - & Relating specific growth rate to net energy gain \\
\hline McNicol et al., 1985 & River & Manitoba, CA & Y & $\mathrm{N}$ & $\begin{array}{l}\text { Investigating the feeding and territorial } \\
\text { behavior of } S \text {. fontinalis fry }\end{array}$ \\
\hline Grant and Noakes, 1986 & River & Ontario, CA & $\mathrm{N}$ & Y & $\begin{array}{l}\text { Comparing the size composition of drifting } \\
\text { invertebrates and those in the stomachs of } \\
\text { S. fontinalis }\end{array}$ \\
\hline Cunjak and Power, 1987 & River & Québek, CA & Y & Y & $\begin{array}{l}\text { Studying the winter feeding of stream dwelling } \\
\text { S. fontinalis }\end{array}$ \\
\hline Grant and Noakes, 1987 & River & Ontario, CA & $\mathrm{N}$ & Y & $\begin{array}{l}\text { Studying alternative feeding tactics in } S \text {. } \\
\text { fontinalis fry }\end{array}$ \\
\hline Fechney, 1988 & River & New Zeland & $\mathrm{Y}$ & $\mathrm{N}$ & Describing the diet of S. fontinalis \\
\hline Grant and Noakes, 1988 & River & Ontario, CA & $\mathrm{N}$ & Y & $\begin{array}{l}\text { Studying the aggressive behavior of } S \text {. } \\
\text { fontinalis fry with different foraging tactics }\end{array}$ \\
\hline Walsh et al., 1988 & River & Québek, CA & Y & Y & $\begin{array}{l}\text { Describing the daily variations in the diet of } \\
\text { S. fontinalis fry }\end{array}$ \\
\hline Grant et al., 1989 & River & Ontario, CA & $\mathrm{N}$ & Y & $\begin{array}{l}\text { Studying the territorial behavior and size of } \\
\text { foraging areas in } S \text {. fontinalis fry }\end{array}$ \\
\hline Hubert and Rodhes, 1989 & River & Wyoming, USA & $\mathrm{Y}$ & $\mathrm{N}$ & Describing the diet of $S$. fontinalis \\
\hline Ensign, 1990 & River & Appalachi, USA & $\mathrm{Y}$ & Y & $\begin{array}{l}\text { Effects of the summer food limitation on the } \\
\text { S. fontinalis biomass }\end{array}$ \\
\hline Bussieres, 1991 & River & Québek, CA & $\mathrm{Y}$ & Y & $\begin{array}{l}\text { Assessing the daily consumption of inverte- } \\
\text { brates in S. fontinalis }\end{array}$ \\
\hline East and Magnan, 1991 & Lake & Canada & Y & $\mathrm{Y}$ & $\begin{array}{l}\text { Assessing the factors regulating piscivory in } \\
\text { S. fontinalis }\end{array}$ \\
\hline Dewald and Wilzbach, 1992 & Mesocosm & - & - & - & $\begin{array}{l}\text { Studying the competition between native } \\
\text { S. fontinalis and introduces Salmo trutta }\end{array}$ \\
\hline Lacasse and Magnan, 1992 & Lake & Québek, CA & $\mathrm{Y}$ & Y & $\begin{array}{l}\text { Determining the abiotic and biotic factors } \\
\text { affecting the diet of } S \text {. fontinalis }\end{array}$ \\
\hline McLaughlin et al., 1992 & River & Ontario, CA & $\mathrm{N}$ & Y & $\begin{array}{l}\text { Studying the foraging movements in S. fontinalis } \\
\text { fry }\end{array}$ \\
\hline
\end{tabular}


Tab. 5. Continued from previous page.

\begin{tabular}{|c|c|c|c|c|c|}
\hline Reference & Habitat & Region & Diet & Native & Objectives \\
\hline Bechara et al., 1993 & Mesocosm & Québec, CA & Y & $\mathrm{Y}$ & $\begin{array}{l}\text { Determining the impact of } S \text {. fontinalis on the } \\
\text { macroinvertebrate fauna }\end{array}$ \\
\hline Curry et al., 1993 & Lake and river & Ontario, CA & $\mathrm{Y}$ & $\mathrm{Y}$ & $\begin{array}{l}\text { Describing the diet and growth of } S \text {. fontinalis } \\
\text { fry }\end{array}$ \\
\hline Forrester et al., 1994 & River & New Hampshire, USA & $\mathrm{Y}$ & $\mathrm{Y}$ & $\begin{array}{l}\text { Studying the determinants of the diet of } \\
\text { S. fontinalis }\end{array}$ \\
\hline Sirois and Boisclair, 1995 & Mesocosm & - & - & - & $\begin{array}{l}\text { Determining the importance of zooplankton for } \\
\text { S. fontinalis fry }\end{array}$ \\
\hline Biro et al., 1995 & River & Ontario, CA & $\mathrm{N}$ & $\mathrm{Y}$ & $\begin{array}{l}\text { Determining if the feeding attempts are good } \\
\text { indicators of the ingestion rates in } S \text {. fontinalis } \\
\text { as a species model }\end{array}$ \\
\hline Elser et al., 1995 & Lake & California, USA & Y & $\mathrm{N}$ & $\begin{array}{l}\text { Food web effects of rainbow trout density } \\
\text { manipulation }\end{array}$ \\
\hline Bourke et al., 1997 & Lake & & & & $\begin{array}{l}\text { Studying the polymorphism in } S \text {. fontinalis in } \\
\text { relation to their foraging habitats }\end{array}$ \\
\hline Cavalli et al., 1997 & Lake & Alps, France & $\mathrm{Y}$ & $\mathrm{N}$ & $\begin{array}{l}\text { Describing the diet and growth rates of } S \text {. } \\
\text { fontinalis }\end{array}$ \\
\hline Duffield and Nelson, 1998 & River & Wyoming, USA & $\mathrm{Y}$ & $\mathrm{Y}$ & $\begin{array}{l}\text { Determining the stonefly component in the diet } \\
\text { of } S \text {. fontinalis }\end{array}$ \\
\hline Macchi et al., 1999 & Lake & Patagonia, Argentina & $\mathrm{Y}$ & $\mathrm{N}$ & $\begin{array}{l}\text { Describing the predation between introduced } \\
\text { and native fish }\end{array}$ \\
\hline Dunham et al., 2000 & River & Nevada, USA & $\mathrm{Y}$ & $\mathrm{N}$ & $\begin{array}{l}\text { Describing the diet of introduced } S \text {. fontinalis } \\
\text { and its daily variation }\end{array}$ \\
\hline Gunckel, 2000 & River & Oregon, USA & Y & $\mathrm{N}$ & $\begin{array}{l}\text { Comparing the diet of native } S \text {. confluentus } \\
\text { and introduced } S \text {. fontinalis }\end{array}$ \\
\hline McLaughlin et al., 2000 & River & Ontario, CA & $\mathrm{N}$ & $\mathrm{Y}$ & $\begin{array}{l}\text { Assessing the predation success of recently } \\
\text { emerged S. fontinalis }\end{array}$ \\
\hline Sweka and Hartman, 2001a & River & Appalachi, USA & Y & $\mathrm{Y}$ & $\begin{array}{l}\text { Describing the fall and winter prey selection in } \\
\text { S. fontinalis }\end{array}$ \\
\hline Sweka and Hartman, 2001b & River & Appalachi, USA & $\mathrm{Y}$ & $\mathrm{Y}$ & $\begin{array}{l}\text { Assessing the effects of water turbidity on prey } \\
\text { consumption }\end{array}$ \\
\hline Sweka and Hartman, 2001c & River & Appalachi, USA & Y & Y & $\begin{array}{l}\text { Assessing the effects of turbidity reactive } \\
\text { distance and foraging success }\end{array}$ \\
\hline Hartman and Sweka, 2001 & Laboratory & & - & - & $\begin{array}{l}\text { Developing a bioenergetics model for } S \text {. } \\
\text { fontinalis }\end{array}$ \\
\hline Milano et al., 2002 & Lake & Patagonia, Argentina & $\mathrm{Y}$ & $\mathrm{N}$ & $\begin{array}{l}\text { Assessing the impact of piscivorous } S \text {. } \\
\text { fontinalis on native fish fauna }\end{array}$ \\
\hline Power et al., 2002 & Lake & Québek, CA & $\mathrm{N}$ & $\mathrm{Y}$ & $\begin{array}{l}\text { Using stable isotope to assess the trophic niche } \\
\text { of S. alpinus and S. fontinalis }\end{array}$ \\
\hline Gowan and Fausch, 2002 & Stream & Rocky mts., USA & $\mathrm{N}$ & $\mathrm{N}$ & Studying the movements of foraging $S$. fontinalis \\
\hline Gunckel et al., 2002 & Stream, mesocosm & Oregon, USA & $\mathrm{N}$ & $\mathrm{N}$ & $\begin{array}{l}\text { Comparing resource partitioning between } \\
\text { S. fontinalis and native salmonids }\end{array}$ \\
\hline Sweka, 2003 & River & Appalachi, USA & Y & Y & $\begin{array}{l}\text { Assessing the aquatic-terrestrial linkages in } \\
\text { streams }\end{array}$ \\
\hline Hilderbrand and Kershner, 2004 & River & Idaho, USA & $\mathrm{Y}$ & $\mathrm{N}$ & $\begin{array}{l}\text { Assessing how introduced } S \text {. fontinalis } \\
\text { compete with native fish species }\end{array}$ \\
\hline Mookerji et al., 2004 & River & Québek, CA & Y & Y & $\begin{array}{l}\text { Describing the interaction between } S \text {. fontinalis } \\
\text { and Salmo salar }\end{array}$ \\
\hline Sweka, 2004 & Laboratory & 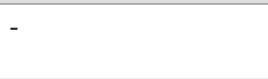 & - & - & $\begin{array}{l}\text { Assessing the gastric evacuation rates of } \\
\text { S. fontinalis }\end{array}$ \\
\hline Thorne, 2004 & River & Appalachi, USA & Y & $\mathrm{Y}$ & $\begin{array}{l}\text { Spatial and seasonal variation in } S \text {. fontinalis } \\
\text { diet }\end{array}$ \\
\hline Webster and Hartman, 2005 & River & West Virginia, USA & $\mathrm{Y}$ & $\mathrm{Y}$ & $\begin{array}{l}\text { Assessing the role of terrestrial insects for the } \\
\text { diet of } S \text {. fontinalis }\end{array}$ \\
\hline Morinville, 2005 & Estuarine areas & Québek, CA & $\mathrm{Y}$ & Y & $\begin{array}{l}\text { The bioenergetic basis of anadromy in } S \text {. } \\
\text { fontinalis }\end{array}$ \\
\hline Sotiropoulos et al., 2006 & River & Massachusetts, USA & $\mathrm{Y}$ & $\mathrm{Y}$ & $\begin{array}{l}\text { Studying habitat selection and diet of } S \text {. } \\
\text { fontinalis fry under low stream flows }\end{array}$ \\
\hline Morinville and Rasmussen, 2006 & Estuarine areas & Québek, CA & Y & Y & $\begin{array}{l}\text { Marine feeding patterns of anadromous } S \text {. } \\
\text { fontinalis }\end{array}$ \\
\hline
\end{tabular}


Tab. 5. Continued from previous page.

\begin{tabular}{|c|c|c|c|c|c|}
\hline Reference & Habitat & Region & Diet & Native & Objectives \\
\hline Vander Zanden et al., 2006 & Lake & California, USA & Y & $\mathrm{N}$ & $\begin{array}{l}\text { Fish production related to benthic } v s \text {. pelagic } \\
\text { trophic pathways }\end{array}$ \\
\hline Utz and Hartman, 2006 & River & Appalachi, USA & Y & Y & $\begin{array}{l}\text { Temporal and spatial variation in the energy } \\
\text { intake of } S \text {. fontinalis }\end{array}$ \\
\hline Barr, 2007 & River & New Hampshire, USA & Y & $\mathrm{Y} / \mathrm{N}$ & $\begin{array}{l}\text { Manipulating habitats (by } S \text {. fontinalis } \\
\text { introduction) to assess the impact on } \\
\text { invertebrates and amphibians }\end{array}$ \\
\hline Cucherousset et al., 2007 & River & Pyrenees, France & $\mathrm{N}$ & $\mathrm{N}$ & $\begin{array}{l}\text { Using stable isotope to assess the trophic } \\
\text { interaction between S. fontinalis and Salmo } \\
\text { trutta }\end{array}$ \\
\hline Macchi et al., 2007 & Mesocosm & - & - & - & $\begin{array}{l}\text { Assessing the impact of piscivorous } S \\
\text { fontinalis on native fish fauna }\end{array}$ \\
\hline McGrath and Lewis, 2007 & River & Colorado, USA & Y & $\mathrm{N}$ & $\begin{array}{l}\text { Assessing how introduced } S \text {. fontinalis } \\
\text { compete with native fish species }\end{array}$ \\
\hline Sánchez et al., 2007 & Lake & Sierra de Gredos, Spain & Y & $\mathrm{N}$ & $\begin{array}{l}\text { Describing the diet of } S \text {. fontinalis and } \\
\text { determining the nutritional quality of different } \\
\text { preys }\end{array}$ \\
\hline Utz and Hartman, 2007 & River & Appalachi, USA & Y & Y & $\begin{array}{l}\text { Determining which prey organisms sustain } \\
\text { S. fontinalis in differnt seasons }\end{array}$ \\
\hline Utz et al., 2007 & River & Appalachi, USA & $\mathrm{Y}$ & $\mathrm{Y}$ & $\begin{array}{l}\text { Assessing the role of terrestrial beetles in the } \\
\text { diet of } S \text {. fontinalis }\end{array}$ \\
\hline Bertrand et al., 2008 & Lake & Québek, CA & Y & Y & $\begin{array}{l}\text { Describing the trophic polymorphism in } S \text {. } \\
\text { fontinalis }\end{array}$ \\
\hline Ojala, 2008 & River & Massachusetts, USA & $\mathrm{Y}$ & $\mathrm{Y}$ & $\begin{array}{l}\text { Studying the feeding interaction between } \\
\text { different fish species }\end{array}$ \\
\hline Sweka and Hartman, 2008 & River & Appalachi, USA & $\mathrm{Y}$ & $\mathrm{Y}$ & $\begin{array}{l}\text { Investigating the role of terrestrial insects for } \\
\text { S. fontinalis }\end{array}$ \\
\hline Hartman and Cox, 2008 & - & - & - & - & $\begin{array}{l}\text { Developing a bioenergetics model for } S \text {. } \\
\text { fontinalis }\end{array}$ \\
\hline Browne and Rasmussen, 2009 & Lake & Ontario, CA & Y & Y & $\begin{array}{l}\text { Studying the feeding interaction between } \\
\text { different fish species }\end{array}$ \\
\hline Farwell and McLaughlin, 2009 & River & Ontario, $\mathrm{CA}$ & $\mathrm{N}$ & $\mathrm{Y}$ & Studying alternative feeding tactics $S$. fontinalis \\
\hline Ferriz et al., 2010 & River & Pampa de Achala, Argentina & $\mathrm{Y}$ & $\mathrm{N}$ & $\begin{array}{l}\text { Describing the distribution and diet of } \\
\text { introduced salmonids }\end{array}$ \\
\hline Wilson and McLaughlin, 2010 & River & Ontario, CA & $\mathrm{N}$ & $\mathrm{Y}$ & $\begin{array}{l}\text { Studying the relationship between brain } \\
\text { morphology and foraging strategies in } S \text {. } \\
\text { fontinalis fry }\end{array}$ \\
\hline Courtwright and May, 2013 & River & Appalachi, USA & $\mathrm{Y}$ & Y & $\begin{array}{l}\text { Determining the effects of reductions in } \\
\text { terrestrial invertebrate subsidies on } S \text {. fontinalis } \\
\text { diet }\end{array}$ \\
\hline Juncos et al., 2013 & Lake & Patagonia, Argentina & Y & $\mathrm{N}$ & Modeling prey consumption of nonnative fish \\
\hline Farwell et al., 2014 & River & Ontario, CA & $\mathrm{N}$ & Y & Studying alternative feeding tactics $S$. fontinalis \\
\hline Skinner et al., 2014 & Lake & Michigan, USA & Y & Y & $\begin{array}{l}\text { Studying the effects of hypolimnetic } \\
\text { oxygenation on the feeding ecology of several } \\
\text { fish species }\end{array}$ \\
\hline Spares et al., 2014 & Estuarine areas, sea & Nova Scotia, Canada & $\mathrm{Y}$ & $\mathrm{Y}$ & Describing the diet of anadromous $S$. fontinalis \\
\hline Tiberti et al., 2014b & Lake and river & Alps, Italy & Y & $\mathrm{N}$ & $\begin{array}{l}\text { Describing the zooplanktonic fraction of the } \\
\text { diet in adult and young } S \text {. fontinalis }\end{array}$ \\
\hline White and Gowan, 2014 & & Appalachi, USA & $\mathrm{N}$ & $\mathrm{Y}$ & Studying the foraging behavior of $S$. fontinalis \\
\hline Wilson et al., 2014 & River & New Hampshire, USA & Y & $\mathrm{Y}$ & $\begin{array}{l}\text { Investigating the role of terrestrial insects for } \\
\text { the diet of S. fontinalis }\end{array}$ \\
\hline Juncos et al., 2015 & Lakes & Patagonia, Argentina & Y & $\mathrm{N}$ & $\begin{array}{l}\text { Studying the trophic interactions between } \\
\text { native and alien fish species }\end{array}$ \\
\hline Kraus et al., 2016 & River & Colorado, USA & Y & $\mathrm{N}$ & $\begin{array}{l}\text { Studying the effects of river pollution on the } \\
\text { diet of } S \text {. fontinalis }\end{array}$ \\
\hline
\end{tabular}

Diet, food composition data are provided $(Y)$ or not $(N)$; native, study from native (Y) or non-native populations (N), but note that we did not check for possible range expansion within the native range of $\mathrm{S}$. fontinalis. 
$366 ; \mathrm{N}=50$ ); the mean biovolume of measured stomach contents was $1.60 \pm 2.70 \mathrm{~mL}$ (range 0.0-35.0; $\mathrm{N}=267$ ) in lakes and $1.68 \pm 2.26 \mathrm{~mL}$ (range $0.0-11.8 \mathrm{~mL} ; \mathrm{N}=37$ ) in rivers. Twenty specimens had empty stomachs.

\section{Factors influencing the diet}

The diversity of ingested preys (number of prey groups found in each stomach) was higher in rivers than in lakes $(\mathrm{Beta}=0.20 ; \mathrm{df}=1 ; \mathrm{F}=8.70 ; \mathrm{P}<0.01)$ and positively affected by the date of sampling $($ Beta $=0.24 ; \mathrm{df}=1$; $\mathrm{F}=36.29 ; \mathrm{P}<0.001)$, while the effect of fish size was not significant $(\mathrm{Beta}=0.03 ; \mathrm{df}=1 ; \mathrm{F}=0.93 ; \mathrm{P}=0.11)$. The abundance of prey items in each stomach depended on the habitat type (rivers vs. lakes: $B e t a=-1.51 ; \mathrm{df}=1 ; \mathrm{F}=17.90$; $\mathrm{P}<0.001)$, fish size $(\mathrm{Beta}=0.44 ; \mathrm{df}=1 ; \mathrm{F}=7202.64$; $\mathrm{P}<0.001$ ) and date of sampling (Beta $=0.75$; $\mathrm{df}=1$; $\mathrm{F}=714.33 ; \mathrm{P}<0.001)$. The biovolume of the stomach contents depended only on the fish size (Beta $=0.31 ; \mathrm{df}=1$; $\mathrm{F}=40.74 ; \mathrm{P}<0.001)$, while the effects of the habitat type and of the date of sampling were not significant.

The GLMs results for the occurrence of each prey group show that habitat type, fish size and date of sampling can have significant effects on different prey groups (Tab. 6). The occurrence of certain prey groups was a significant predictor of the presence of others groups. The occurrence of zooplankton and nektonic invertebrates is higher in the diet of lake dwelling $S$. fontinalis while benthonic invertebrates are more related to the riverine diet. Zooplankton, nektonic invertebrates and fossorial invertebrates are negatively influenced by fish size, while the occurrence of terrestrial insects and vertebrates is higher in larger size classes. The presence of bethonic and fossorial invertebrates is also influenced by the date of sampling suggesting the existence of some seasonality in $S$. fontinalis food composition. There is a mutual negative effect between the presence of terrestrial invertebrates and zooplankton, and a positive one between bentonic and fossorial invertebrates (Tab. 6).

\section{DISCUSSION}

\section{A short review on the feeding ecology of Salvelinus fontinalis}

The feeding ecology of native and introduced S. fontinalis populations has been extensively studied and was partially reviewed in Ricker (1932) and Balon (1980). In general, the feeding ecology of $S$. fontinalis is characterized as opportunistic. Prey belong to many taxonomic and functional groups, often representing the most abundant/accessible prey in the studied habitats. This general pattern is accurate throughout the existing literature, but prey composition can vary a lot depending on several abiotic and biotic factors and prey specialization can sometimes occur.
Most of the studies on the feeding ecology of $S$. fontinalis include some direct description of the diet obtained by dissecting or flushing their stomachs. Due to its opportunistic behavior, prey availability is probably the most important factor determining the food composition in $S$. fontinalis (Lacasse and Magnan, 1992). The literature reflects this general finding providing many examples of measurements of prey availability (lists or quantitative measures of benthic and drifting invertebrates, zooplankton, and sympatric fish and amphibians). More recently the importance of terrestrial insect subsidies in aquatic environments has become evident and measures or manipulations of terrestrial prey have been included in the studies concerning the feeding ecology of $S$. fontinalis (Webster and Hartman, 2005; Utz and Hartman, 2007; Sweka and Hartman, 2008; Courtwright and May, 2013; Wilson et al., 2014).

Also the habitat is very important in determining the availability of prey and the diet of $S$. fontinalis. There are several studies from lotic, lentic, and estuarine habitats (Tab. 5). In lotic systems, drifting prey from upstream river course are usually the most important food resource; in lakes, or under reduced levels of water discharge, nondrifting invertebrates and terrestrial prey become dominant (Dawidowicz and Gliwicz, 1983; Sotiropoulos et al., 2006); in estuarine habitats, adult anadromous fish are mainly piscivorous (Spares et al., 2014). The presence of ecological refuges (e.g., aquatic vegetation, aphotic zone, rock interstices) is a recognized factor enhancing the resistance of prey communities (Bechara et al., 1993; Williamson et al., 2011), but its influence on the diet of $S$. fontinalis is little documented (Bechara et al., 1993).

S. fontinalis usually lives in climates with strong seasonal patterns (e.g., alpine and circumpolar climates) and temporal (both daily and seasonal) variations in prey availability affect its diet (Benson, 1954; Allan, 1981; Dawidowicz and Gliwicz, 1983; Cunjak and Power, 1987; Utz and Hartman, 2007). In the complex, the studies on the diet of $S$. fontinalis are biased towards the description of the summer diet. The few studies including winter sampling provide important insight into the overwintering strategies of $S$. fontinalis, which continue to feed mostly/exclusively on the aquatic prey (Benson, 1954; Dawidowicz and Gliwicz, 1983; Utz and Hartman, 2007; Spares et al., 2014). The diet of $S$. fontinalis varies with the age and the size, shifting from small invertebrates to large invertebrates and vertebrates (Allan, 1981; Lacasse and Magnan, 1992), but adult fish maintain the ability to feed on relatively small prey items (e.g., zooplankton larger than $\approx 1.2 \mathrm{~mm}$; Tiberti et al., 2014b) which can became dominant food resource in the absence of large prey. The diet of young $S$. fontinalis is the specific objective of several articles (Tab. 5). Dietary data have been used also to describe interaction between native or introduced $S$. 
fontinalis with other fish species. The impact can be mediated by predation on both juvenile and adult sympatric species, or by competition (Dewald and Wilzbach, 1992; Macchi et al., 1999). Dietary analyses are often used to get information on the direct predation on sympatric fish populations (East and Magnan, 1991; Milano et al., 2002) or to determine if there is a segregation of the dietary niche between native and introduced species, potentially favoring their coexistence (Dewald and Wilzbach, 1992). Outside its native range, $S$. fontinalis can have very strong impacts on the native population of small-size fish (Macchi et al., 1999; Milano et al., 2002) and displace native species (McGrath and Lewis, 2007). Within its native range $S$. fontinalis is threatened by the introduction of non-native Salmonids such as Salmo trutta and Oncorhynchus mykiss, which are seriously shrinking its original range (Dewald and Wilzbach, 1992). However $S$. fontinalis can coexist in competition with several fish species. In these cases there is usually a large dietary niche overlap between the competing species (Griffith, 1974), and it is probable that food resource segregation is not the best factor explaining the ability of $S$. fontinalis to survive in sympatry.

There are some studies addressing the existence of different feeding strategies and specializations in $S$. fontinalis (Grant and Noakes, 1986; Grant and Noakes, 1987; Bourke et al., 1997; Bertrandt et al., 2008; Wilson and McLaughlin, 2010). These studies are individual-based ethological studies and, in the complex, they combine diet, behavioral, genetic, and morphological data to show the ethological, anatomical, and evolutionary consequences of food segregation. The existence of different foraging strategies and of trophic polymorphism in $S$. fontinalis is often documented recording the movements, successful and unsuccessful predation attempts, and territorial behavior in S. fontinalis (McNicol et al., 1985; Grant and Noakes, 1988; Grant et al., 1989; McLaughlin et al., 1992; Farwell and McLaughlin, 2009) or relating the feeding behavior with morphological traits (Bourke $e t$ al., 1997; Bertrand et al., 2008; Wilson and McLaughlin, 2010). These ethological studies often used young $S$. fontinalis as model species, while similar studies on adults are absent. In the complex individual feeding specialization is little studied even if it is believed to be at the basis

Tab. 6. Fixed effect results from generalized mixed effects models testing the effects of habitat (stream vs lake), fish size classes, sampling date and presence/absence of other prey groups on the presence of each prey group identified in the diet of Salvelinus fontinalis. The year and the sampling site identity were added as random effects. All the observations $(\mathrm{N}=507)$ have been collected over nine years (2006-2014) at 16 sampling sites (8 streams and 8 lakes) in the Gran Paradiso National Park.

\begin{tabular}{|c|c|c|c|c|c|c|c|c|c|}
\hline Model & Fixed term & Beta & $95 \% \mathrm{CI}$ & RVI & Model & Fixed term & Beta & $95 \% \mathrm{CI}$ & RVI \\
\hline $\begin{array}{l}\text { Zooplankton } \\
\text { (Group-1) }\end{array}$ & $\begin{array}{c}\text { Intercept } \\
\text { Habitat } \\
\text { Size } \\
\text { Date } \\
\text { Group-2 } \\
\text { Group-3 } \\
\text { Group-4 } \\
\text { Group-5 } \\
\text { Group-6 }\end{array}$ & $\begin{array}{c}1.86 \\
-3.08 \\
-0.89 \\
-0.05 \\
0.09 \\
-0.12 \\
-0.14 \\
-1.27 \\
0.50\end{array}$ & $\begin{array}{cc}-0.11 & 3.81 \\
-5.67 & -0.49 \\
-1.18 & -0.60 \\
-0.91 & 0.47 \\
-0.43 & 1.07 \\
-1.39 & 0.55 \\
-1.21 & 0.38 \\
-2.02 & -0.53 \\
-0.98 & 3.78\end{array}$ & $\begin{array}{c}- \\
1.00 \\
1.00 \\
0.23 \\
0.30 \\
0.28 \\
0.34 \\
1.00 \\
0.36\end{array}$ & $\begin{array}{l}\text { Nektonic invertebrates } \\
\text { (Group-2) }\end{array}$ & $\begin{array}{c}\text { Intercept } \\
\text { Habitat } \\
\text { Size } \\
\text { Date } \\
\text { Group-1 } \\
\text { Group-3 } \\
\text { Group-4 } \\
\text { Group-5 } \\
\text { Group-6 }\end{array}$ & $\begin{array}{c}0.48 \\
\underline{-1.32} \\
\underline{-0.16} \\
0.05 \\
0.01 \\
0.05 \\
0.03 \\
0.13 \\
-0.01\end{array}$ & $\begin{array}{cc}-0.58 & 1.55 \\
-2.55 & -0.05 \\
-0.31 & -0.02 \\
-0.16 & 0.47 \\
-0.64 & 0.73 \\
-0.34 & 0.76 \\
-0.31 & 0.58 \\
-0.16 & 0.77 \\
-1.20 & 1.11\end{array}$ & $\begin{array}{c}- \\
\underline{0.87} \\
\underline{0.98} \\
0.31 \\
0.15 \\
0.24 \\
0.20 \\
0.41 \\
0.15\end{array}$ \\
\hline $\begin{array}{l}\text { Benthonic invertebrates } \\
\text { (Group-3) }\end{array}$ & $\begin{array}{c}\text { Intercept } \\
\text { Habitat } \\
\text { Size } \\
\text { Date } \\
\text { Group-1 } \\
\text { Group-2 } \\
\text { Group-4 } \\
\text { Group-5 } \\
\text { Group-6 }\end{array}$ & $\begin{array}{c}-4.01 \\
\underline{3.51} \\
0.16 \\
\underline{2.58} \\
-0.42 \\
0.00 \\
\underline{0.69} \\
0.11 \\
0.07\end{array}$ & 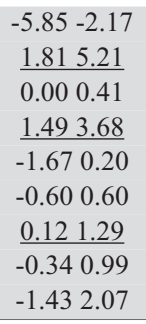 & $\begin{array}{c}- \\
1.00 \\
0.76 \\
1.00 \\
0.58 \\
0.18 \\
0.98 \\
0.35 \\
0.22\end{array}$ & $\begin{array}{l}\text { Aquatic fossorial } \\
\text { invertebrates } \\
\text { (Group-4) }\end{array}$ & $\begin{array}{c}\text { Intercept } \\
\text { Habitat } \\
\text { Size } \\
\text { Date } \\
\text { Group-1 } \\
\text { Group-2 } \\
\text { Group-3 } \\
\text { Group-5 } \\
\text { Group-6 }\end{array}$ & $\begin{array}{c}0.51 \\
-0.11 \\
\underline{-0.23} \\
\underline{0.36} \\
-0.47 \\
0.01 \\
\underline{0.69} \\
0.15 \\
-0.01 \\
\end{array}$ & 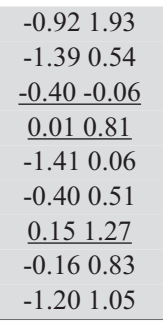 & $\begin{array}{c}- \\
0.27 \\
\underline{1.00} \\
\underline{0.87} \\
0.70 \\
0.16 \\
\underline{0.98} \\
0.44 \\
0.16\end{array}$ \\
\hline $\begin{array}{l}\text { Terrestrial insects } \\
\text { (Group-5) }\end{array}$ & $\begin{array}{l}\text { Intercept } \\
\text { Habitat } \\
\text { Size } \\
\text { Date } \\
\text { Group-1 } \\
\text { Group-2 } \\
\text { Group-3 } \\
\text { Group-4 } \\
\text { Group-6 }\end{array}$ & $\begin{array}{c}0.34 \\
-0.39 \\
\underline{0.21} \\
0.08 \\
-1.26 \\
0.15 \\
0.05 \\
0.15 \\
-0.59\end{array}$ & $\begin{array}{cc}-0.65 & 1.33 \\
-1.32 & 0.11 \\
\underline{0.04} & 0.39 \\
-0.11 & 0.51 \\
-1.94 & -0.58 \\
-0.13 & 0.76 \\
-0.45 & 0.82 \\
-0.14 & 0.80 \\
-2.04 & 0.10\end{array}$ & \begin{tabular}{c|}
- \\
0.64 \\
0.97 \\
0.42 \\
1.00 \\
0.48 \\
0.29 \\
0.48 \\
0.61
\end{tabular} & $\begin{array}{l}\text { Vertebrates } \\
\text { (fish and frogs) } \\
\text { (Group-6) }\end{array}$ & $\begin{array}{l}\text { Intercept } \\
\text { Habitat } \\
\text { Size } \\
\text { Date } \\
\text { Group-1 } \\
\text { Group-2 } \\
\text { Group-3 } \\
\text { Group-4 } \\
\text { Group-5 }\end{array}$ & $\begin{array}{c}-12.13 \\
1.35 \\
1.47 \\
0.17 \\
0.25 \\
0.02 \\
0.07 \\
0.02 \\
-0.31\end{array}$ & 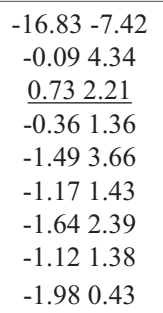 & \begin{tabular}{c|}
- \\
0.64 \\
1.00 \\
0.34 \\
0.24 \\
0.13 \\
0.18 \\
0.13 \\
0.41
\end{tabular} \\
\hline
\end{tabular}

Beta, averaged parameter estimate; CI, confidence intervals; RVI, Relative Variable Importance (from 0 to 1 ). 
of the existence of different morphotypes in many S. fontinalis populations. On the contrary, this issue demonstrated to be a fertile research field in the congeneric species $S$. alpinus, which is considered a classic model for studies of trophic specialization (Jonsson and Jonsson, 2001). Laboratory and mesocosm studies were used to measure several metabolic parameters (optimal feeding, energy requirements, rates of food consumption, and evacuation rates; Morgulis, 1918; Titcomb et al., 1928; Detwiler, 1930; Sweka, 2004), to study competition between native and introduced fish (Magnan and FitzGerald, 1984; Dewald and Wilzbach, 1992), or to understand the predatory impact of S. fontinalis (Bechara et al., 1993; Sirois and Boisclair, 1995; Macchi et al., 2007). The latter studies are particularly interesting to understand the invasion ecology of $S$. fontinalis.

Without the intent to review all the existing literature on the ecological impact of introduced S. fontinalis, the most common experimental approach to assess its impact is to compare the native communities of invaded and noninvaded habitats (Tiberti et al., 2014a) or before and after fish introductions (Schabetsberger et al., 2009) and eradications (Knapp et al., 2001). In many cases dietary data are not provided, but the pervasive impact of introduced S. fontinalis is ascribed to the selective predation on more visible preys and ultimately on its feeding ecology.

\section{Factors influencing the diet}

Our results confirm that $S$. fontinalis is an opportunistic predator (Lacasse and Magnan, 1992). However prey composition varied a lot between and within the populations depending on several abiotic and biotic factors influencing prey availability. Habitat type and fish size played an important role in determining the food composition in S. fontinalis, and there are some evidences of the seasonal variation in food composition. These results are similar to what described in literature, confirming many of the current knowledge on the feeding ecology of $S$. fontinalis.

\section{Prey availability}

Prey availability is probably the most important factor determining the food composition of generalist predators, such as S. fontinalis (Allan, 1981; Lacasse and Magnan, 1992; Cavalli et al., 1997). Virtually all the available preys are present in the diet of $S$. fontinalis, with the exception of some very small aquatic and terrestrial taxa (e.g., Rotifera and terrestrial Acarina; Tab. 5), which are probably invisible to $S$. fontinalis. There is a general consistency between the frequencies of occurrence of prey taxa in the stomachs and in the samples for prey availability. Nevertheless some clear discordances between prey availability and prey consumption have been observed. Arctodiaptomus alpinus is the second most common crustacean in- habiting the studied lakes $(\mathrm{F} \%=70 \%)$ and is a large zooplankton species (up to $2 \mathrm{~mm}$ ); therefore, it should be a rather common prey for $S$. fontinalis, but it is only the $9^{\text {th }}$ zooplankton prey in order of frequency of occurrence in the stomach contents. A rapid digestion (but all the other zooplankton species were usually well recognizable) or the existence of effective anti-predator adaptations are possible explanations. Oligochaeta are underrepresented in the diet of $S$. fontinalis, perhaps due to their poor resistance to digestion which can hamper their observation (Hyslop, 1980). Some aquatic macroinvertebrate taxa are also underrepresented in the diet of stream dwelling $S$. fontinalis (e.g., Simulid larvae and bivalves) while Chironomid pupae are clearly overrepresented in the diet of both stream and lake dwelling $S$. fontinalis. As a matter of facts, stream dwelling $S$. fontinalis feed mainly of drifting macroinvertebrates (Allan, 1981), suggesting that drift, rather than benthic samples, would return a better quantification of prey availability. Underrepresented taxa would belong to non-drifting macroinvertebreates, while Chironomid pupae are usually a significant part of the drift (Fechney, 1988). Diptera pupae are also overrepresented in the diet of lake dwelling S. fontinalis possibly indicating that this prey item is actively searched and positively selected by $S$. fontinalis. Concerning terrestrial insects, the presence of terrestrial prey in the stomachs reflect the measures of prey availability, in particular those related to the invertebrates falling into the lakes which are nearly all winged insects (Diptera and Coleoptera). Non-winged invertebrates (e.g., Aranea and Miriapoda) are usually underrepresented in the diet of $S$. fontinalis, even if they could be abundant around the lakes. The measures of prey availability around the lakes do not take into account that some taxa (e.g., winged insects) are more likely to fall into the water.

\section{Habitat: streams vs lakes}

Most of the differences between the diet of stream and lake dwelling S. fontinalis (Tabs. 3 and 4) should be ascribed to the different prey availability in lakes and streams. For example zooplankton can be found only in lakes and many aquatic invertebrates (e.g., Tricoptera, Ephemeroptera, and Plecoptera) are much more common in rivers. The food composition of $S$. fontinalis clearly reflects these differences.

The abundance of ingested prey items was higher in lakes than in streams, but the biovolumes were not influenced by habitat type, indicating that lake dwelling S. fontinalis have to catch a greater number of smaller prey to achieve their energy requirements. According to its size selective predation strategy (Allan, 1981), S. fontinalis can shift towards suboptimal smaller prey when large prey are absent. Drifting insects from non-invaded upstream stretch probably supply $S$. fontinalis with large invertebrates from 
non-impacted habitats, while large aquatic prey are strongly impacted and therefore unavailable in lakes (Tiberti et al., 2014 a), forcing $S$. fontinalis to feed on smaller prey.

\section{Fish size}

Fish size is an important factor determining the diet of $S$. fontinalis (Allan, 1981). It negatively influences the consumption of zooplankton, and of fossorial and nektonic aquatic invertebrates, and positively influences the consumption of vertebrates and terrestrial insects (Tab. 3). In the complex we observed a shift from a diet based on zooplankton and aquatic invertebrates (mostly small invertebrates such as chironomid diptera), typical of small fish, to a diet including increasing quantities of larger preys such as terrestrial insects and vertebrates, typical of adult fish. This is consistent with a size selective predation strategy, which optimize feeding behavior by increasing the energy content per prey and reducing the number of predation attempts (Griffiths, 1980). This strategy is a common feeding strategy of aquatic visual predators, such as salmonids, in general, and S. fontinalis, in particular (Allan, 1981). However the size range of the ingested preys is constrained by the predator visual capacity (O’Brien, 1979) and mouth size (Wankowski, 1979). Small fish can see smaller prey, which are invisible/unavailable to larger fish (O’Brien, 1979). For example zooplankton have been regularly found in the diet of young fish, and smaller species (e.g., chydorid cladocerans) can be found only in smaller fish. However adults maintain the ability to feed on larger crustaceans which represent just a marginal fraction of their diet (Tiberti et al., 2014b).

A strong selective predation can wipe out large preys (Tiberti et al., 2014a), in these cases $S$. fontinalis can opportunistically shift its diet towards sub-optimal prey and this could explain the relatively frequent presence of small prey in the stomachs of adult fish (e.g., zooplankton, chironomid larvae and pupae). Cannibalism and predation over large vertebrates has been observed only in adult fish feeding on $S$. fontinalis (up to $21.5 \mathrm{~cm}$ ) and $R$. temporaria (including large adult specimens) and is the clearest expression of the size selective strategy of $S$. fontinalis. Sometimes ingested prey were so large that they could not be ingested entirely. Cannibalism was observed in 1.89\% of the analyzed stomachs, but it probably plays a very important role in regulating the population structure of $S$. fontinalis (Frenette and Dodson, 1984) and the distribution and behavior of small and medium size fish.

\section{Seasonality}

Prey availability is often dominated by seasonal cycles, especially in the alpine environment, which is subject to extreme seasonal changes. Our study is limited to the ice free season and the most important seasonal factors (ice cover and overwintering phenology of prey taxa) (Leonard, 1941; Benson, 1954; Dawidowicz and Gliwicz, 1983; Cunjak and Power, 1987; Utz and Hartman, 2007) are therefore excluded from our study period. However some increasing seasonal trends have been observed for fossorial and benthonic aquatic invertebrates probably reflecting a greater availability of these prey groups. Aquatic invertebrates are by far the most important food resource during the winter (Benson, 1954; Dawidowicz and Gliwicz, 1983) and, at the beginning of summer, they could be still affected by winter predation. Aquatic invertebrates communities could progressively expand during the summer, thanks to a lighter predation pressure determined by a dietary shift towards terrestrial prey. Terrestrial insects are indeed a very important summer temporary resource (Dawidowicz and Gliwicz, 1983; Webster and Hartman, 2005; Sweka and Hartman, 2008; Wilson et al., 2014) and they are a strategic resource to enable $S$. fontinalis to accumulate sufficient energy resources to overcome the winter poor feeding conditions (Utz and Hartman, 2007).

\section{Feeding specialization}

Putting the presence/absence of the alternative prey groups as covariates in the models enabled us to check if the presence of a certain prey group was a good predictor of the presence of the other ones, indicating possible associations or mechanisms of exclusion between prey groups. We found that benthic and fossorial invertebrates are positively associated, indicating that $S$. fontinalis feeding in the benthic area are able to find both the prey types, probably stirring up the sediment. Moreover we found that zooplankton and terrestrial insects are negatively associated. This could be due to the different habitat where zooplankton and terrestrial insects can be found (pelagic vs. water surface and littoral areas), to the fact that zooplankton prey selection is different in small and large $S$. fontinalis, or to a specialized feeding strategy in S. fontinalis. Zooplanktivorus morphotypes have been indeed described for adult $S$. fontinalis, however zooplankton was just a marginal resource in the studied populations (at least during the ice-free season) and occurred mixed with other prey groups in the stomachs, suggesting that zooplanktivory is an opportunistic rather than a specialized behavior. In the absence of individual-based studies (Wilson et al., 2010) it is impossible to disentangle between feeding specialization and opportunistic feeding on a locally/temporally abundant prey. However feeding specialization has been observed several times in S. fontinalis (Bryan and Larkin, 1972; Grant and Noakes, 1986; Grant and Noakes, 1987; Bourke et al., 1997; Bertrandt et al., 2008; Wilson et al., 2010) and occurs when prey availability ceases to be the most important factor determining the diet and different feeding strategies are put into practice. Feed- 
ing specialization can last for a limited period -for example different feeding strategies (leading to different food composition) have been described in S. fontinalis fry (Grant and Noakes, 1987) - or occur at a certain time of the life of S. fontinalis - as in the case of S. fontinalis which feed exclusively on vertebrate prey. This kind of specialization has probably been observed just once, in lake Djouan, where two very large fish $(>35 \mathrm{~cm})$ were found with adult frogs and fish in their stomachs and no other prey items. Instead the other cases of cannibalism or predation over vertebrates seem to fall within the usual opportunistic behavior of $S$. fontinalis, since other prey items occurred at the same time in the stomachs, and the analyzed fish were within the usual size range of the studied populations of $S$. fontinalis. For the congeneric species S. alpinus, a shift to a cannibalistic specialized diet is believed to occur when a certain critic size is reached (Mittelbach and Persson, 1998; Jonsson and Jonsson, 2001).

\section{$S$. fontinalis diet and its ecological impact}

Introduced fish can affect native prey species (Knapp et al., 2001) and produce indirect cascading effects both in high altitude/latitude lakes and rivers ((Sarnelle and Knapp, 2005; Reissing et al., 2006; Buria et al., 2007). In particular S. fontinalis is one of the most used fish for stocking programs and is a size-selective generalist predators which can rely on a large number of prey and usually prefer larger ones. However the food composition of $S$. fontinalis reflects the availability of prey and many highly impacted potential prey cannot be found in its diet if they were already brought to extinction. Therefore the diet is often dominated by the less impacted survival organisms, with an higher resistance to fish introduction. The impact of $S$. fontinalis in the lakes of the GPNP have been recently quantified (Tiberti and von Hardenberg, 2012; Magnea et al., 2013; Tiberti et al., 2014a, 2014b) and the diet of lake dwelling $S$. fontinalis accurately attain this general role. The most impacted aquatic organisms, such as large zooplankton species (Daphnia sp. and Cyclops gr. abyssorum) and many nektonic and benthonic invertebrates (Tricoptera, Coleoptera, Plecoptera, Acarina) (Tiberti et al., 2014a), are indeed secondary food resources, while fossorial invertebrates, which are not impacted or even favored by introduced fish (Tiberti et al., 2014a), and small sized diptera pupae represent a substantial part of its diet. It is likely that after leading to local extinction or collapse many of its favorite prey, S. fontinalis finally established an equilibrium with some of its sub-optimal prey, such as chironomids. This is also confirmed by Dawidowicz and Gliwicz (1983), who found that chironomids (larvae and pupae) dominate the diet of S. fontinalis in an oligotrophic lake.

During the eradication actions provided within the BIOAQUAE project we manipulated the density of $S$. fontinalis in four lakes and we had the opportunity to observe how the diet of $S$. fontinalis changed while the ecosystems were recovering to their previous fishless state. Already during the eradication, many previously absent taxa rapidly colonized the lakes and were found not only in the samples for prey availability, but also in the diet of S. fontinalis. This confirms that the potential/optimal diet of $S$. fontinalis could be quite different from what can be observed in already strongly impacted habitats (Tiberti et al., 2014c). Diet data also allow a better understanding of certain unclear aspects concerning the impact of $S$. fontinalis in the alpine lakes of the GPNP. Arctodiaptomus alpi$n u s$ is weakly or not impacted by S. fontinalis (Tiberti et al., 2014a), which is a very uncommon finding since large calanoid copepods are considered very sensitive to introduced fish (Brancelj, 1999). The scarce presence of Arctodiaptomus alpinus in the diet of S. fontinalis could provide an explanation of the low ecological impact, and it rises some interrogatives about the reasons and the possible adaptations enabling the relatively undisturbed survival of Arctodiaptomus alpinus. Some behavioral aspects concerning the vertical migrations of Arctodiaptomus alpinus have been explored (Tiberti and Iacobuzio, 2013) but this issue would deserve an in-depth study.

Situation is different for stocked streams, where many sensitive taxa -which are strongly impacted in lakes (e.g., nektonic and benthonic invertebrates; Tiberti et al., 2014a)- are abundant and represent the most important food resource for stream dwelling S. fontinalis (Tab. 5). A weaker impact of fish predation is frequently reported in streams (Bechara et al., 1993 and contained references) and, also in our study area, the impact of S. fontinalis seems to be less dramatic than in lakes. Among all the possible explanations, streams could have an higher habitat diversity providing many refugia against predation (e.g., rock interstices), drifting insects could be a source of immigrant invertebrates masking the effects of predation, or drifting insects -from upstream non-invaded areasand terrestrial insects could supply S. fontinalis with a sufficient quantity of food to ease the predatory pressure on the benthic community (Bechara et al., 1993).

Terrestrial invertebrates are exogenous prey which represent a substantial fraction of the diet of both lake and stream dwelling S. fontinalis (present study; Dawidowicz and Gliwicz, 1983; Wilson et al., 2014). Fish predation does not affect the magnitude of terrestrial insects subsidies -even if the density of some riparian species could hypothetically be affected- but it can affect the nutrient balance of stocked lakes and rivers, metabolizing (by bioaccumulation or excretion) and transferring to the water column the nutrients contained in terrestrial invertebrates (Eby et al., 2006). Indeed fish are believed to serve as a net source of nutrients, potentially affecting the trophic state of the lakes and altering the equilibria be- 
tween benthic and pelagic primary production (Vander Zanden and Vadeboncoeur, 2002). Even if they are rarely found in the diet of $S$. fontinalis, also frogs -amphibians in general- could provide a disproportionate additional input of nutrients from the terrestrial area into the aquatic ecosystems. Due to the substantial contribution of Rana temporaria to the total prey biovolume (Tab. 5), nutrients from amphibians could influence the nutrient balance. However, unlike terrestrial insects, amphibians are highly impacted by introduced fish and they are usually absent from the prey pool available for S. fontinalis (Bradford et al., 1994; Tiberti and von Hardenberg, 2012).

\section{CONCLUSIONS}

S. fontinalis is one of the most problematic introduced fish predator in the Alps and in Europe. Dietary data are a basic tool for the understanding of its ecological impact and our study provides an extensive investigation on its diet from the Alpine region. Our results were very useful for the interpretation of some of the impacts observed in our study area (Gran Paradiso National Park) and could be useful to anyone interested in the invasion ecology of this species in the alpine environment. We complemented our study with an exhaustive literature review on the feeding ecology of native and introduced $S$. fontinalis, providing a comprehensive view on the current and past research areas.

\section{ACKNOWLEDGMENTS}

The authors would like to thank Bruno Bassano, Achaz von Hardenberg (Gran Paradiso National Park) and Giuseppe Bogliani (University of Pavia) for the support and contribution to the research program. Special thanks to the Park wardens for their help and hospitality and to all the students who help us during the field and laboratory work. Funding and logistic support for this research was provided by the Gran Paradiso National Park within the framework of the FP7 ACQWA Project (Assessment of Climatic Change and Impacts on the Quantity and Quality of Water, grant Agreement No. 212250) and the LIFE+ project BIOAQUAE (Biodiversity Improvement of Aquatic Alpine Ecosystems, LIFE11 BIO/IT/000020).

\section{REFERENCES}

Adams SB, Frissell CA, Rieman BE, 2001. Geography of invasion in mountain streams: consequences of headwater lake fish introductions. Ecosystems 4:296-307.

Allan JD, 1978a. Diet of brook trout (Salvelinus Fintinalis, Mitchell) and brown trout (Salmo Trutta, L.) in an Alpine Stream. Verh. Internat. Verein. Limnol. 20:2045-2050.

Allan JD, 1978b. Trout predation and the size composition of stream drift. Limnol. Oceanogr. 23:1231-1237.

Allan JD, 1981. Determinants of diet of brook trout (Salvelinus fontinalis) in a mountain stream. Can. J. Fish. Aquat. Sci. 38:184-192.
Allen GH, Claussen LG, 1960. Selectivity of food by brook trout in a Wyoming beaver pond. Trans. Am. Fish. Soc. 89:80-81.

Baldwin NS, 1957. Food consumption and growth of brook trout at different temperatures. Trans. Am. Fish. Soc. 86:323-328.

Balon EK, 1980. Charrs. Salmonid fishes of the genus Salvelinus. W. Junk Publishers, Boston: 928 pp.

Bahls P, 1992. The status of fish populations and management of high mountain lakes in the western United States. Northwest Sci. 66:183-93.

Barr GE, 2007. The roles of brook trout and larval two-lined salamanders as predators in streams. $\mathrm{PhD}$ thesis, University of New Hampshire: 100 pp.

Bartón K, 2011. MuMIn: Multi-model inference. R package version 1.6.5. http://CRAN.R-project.org/package=MuMIn.

Bechara JA, Moreau G, Hare L, 1993. The impact of brook trout (Salvelinus fontinalis) on an experimental stream benthic community: the role of spatial and size refugia. J. Anim. Ecol. 1993:451-464.

Bellati A, Tiberti R, Cocca W, Galimberti A, Casiraghi M, Bogliani G, Galeotti P, 2014. A dark shell hiding great variability: a molecular insight into the evolution and conservation of melanic Daphnia populations in the Alps. Zool. J. Lin. Soc. 171:697-715.

Benson NG, 1954. Seasonal fluctuations in the feeding of brook trout in the Pigeon River, Michigan. Trans. Am. Fish. Soc. 83:76-83.

Bertrand M, Marcogliese DJ, Magnan P, 2008. Trophic polymorphism in brook charr revealed by diet, parasites and morphometrics. J. Fish Biol. 72:555-572.

Biro PA, Ridgway MS, McLaughlin RL, 1996. Does the rate of foraging attempts predict ingestion rate for young-of-theyear brook trout (Salvelinus fontinalis) in the field? Can. J. Fish. Aquat. Sci. 53:1814-1820.

Bourke P, Magnan P, Rodriguez MA, 1997. Individual variations in habitat use and morphology in brook charr. J. Fish Biol. 51:783-794.

Bradford DF, Graber DM, Tabatabai F, 1994. Population declines of the native frog, Rana muscosa, in Sequoia and Kings Canyon National Parks, California. Southwest. Nat::323-327.

Brancelj A, 1999. The extinction of Arctodiaptomus alpinus (Copepoda) following the introduction of charr into a small alpine lake Dvojno Jezero (NW Slovenia). Aquat. Ecol. 33:355-361.

Browne DR, Rasmussen JB, 2009. Shifts in the trophic ecology of brook trout resulting from interactions with yellow perch: an intraguild predator-prey interaction. Trans. Am. Fish. Soc. 138:1109-1122.

Bryan JE, Larkin PA, 1972. Food specialization by individual trout. J. Fish. Board Can. 29:1615-1624.

Buffagni A, Erba S, 2007. [Macroinvertebrati acquatici e Direttiva 2000/60/EC (WFD)- Parte A. Metodo di campionamento per i fiumi guadabili].[in Italian]. IRSA-CNR, Notiziario dei Metodi Analitici. 1:2-27.

Buria L, Albariño R, Villanueva VD, Modenutti B, Balseiro E, 2007. Impact of exotic rainbow trout on the benthic macroinvertebrate community from Andean-Patagonian headwater streams. Fund. Appl. Limnol. 168:145-154.

Bussieres D, 1991. [Estimation de la consommation journaliere d'invertébres par une population d'Omble de Fontaine 
(Salvelinus fontinalis)]. [MD Thesis in French]. Laval University, Quebec, Canada.

Cavalli L, Chappaz R, Bouchard P, Brun G, 1997. Food availability and growth of the brook trout, Salvelinus fontinalis (Mitchill), in a French Alpine lake. Fish. Manag. Ecol. 4: 167-177.

Clemens WA, 1928. The food of trout from the streams of Oneida County, New York State. Trans. Am. Fish. Soc. 58:183-197.

Clemens WA, Dymond JR, Bigelow NK, 1924. Food studies of Lake Nipigon fish. University of Toronto Stud. Biol. 25.

Cole FR, Medeiros AC, Loope LL, Zuehlke WW, 1992. Effects of the Argentine ant on arthropod fauna of Hawaiian highelevation shrubland. Ecol. 73:1313-1322.

Courtwright J, May CL, 2013. Importance of terrestrial subsidies for native brook trout in Appalachian intermittent streams. Freshwat. Biol. 58:2423-2438.

Cucherousset J, Aymes JC, Santoul F, Céréghino R, 2007. Stable isotope evidence of trophic interactions between introduced brook trout Salvelinus fontinalis and native brown trout Salmo trutta in a mountain stream of south-west France. J. Fish Biol. 71:210-223.

Cunjak R, Power G, 1987. The feeding and energetics of streamresident trout in winter. J. Fish Biol. 31:493-511.

Curry RA, Allen S, Fox MG, Morgan GE, 1993. Growth and food of young-of-the-year brook charr, Salvelinus fontinalis, in lake and creek environments. Env. Biol. Fish. 37:131-138.

Dawidowicz P, Gliwicz ZM, 1983. Food of brook charr in extreme oligotrophic conditions of an alpine lake. Env. Biol. Fish. 8:55-60.

Detwiler J, 1930. Feeding experiments with brook trout fingerlings. Trans. Am. Fish. Soc. 60:146-157.

Dewald L, Wilzbach MA, 1992. Interactions between native brook trout and hatchery brown trout: effects on habitat use, feeding, and growth. Trans. Am. Fish. Soc. 121:287-296.

Duffield RM, Nelson CH, 1998. Stoneflies (Plecoptera) in the diet of brook trout (Salvelinus fontinalis Mitchell) in Libby Creek, Wyoming, USA. Hydrobiologia 380:59-65.

Dunham JB, Rahn ME, Schroeter RE, Breck SW, 2000. Diets of sympatric Lahontan cutthroat trout and nonnative brook trout: implications for species interactions. West. North Am. Natur. 60:304-310.

Dutil JD, Power G, 1980. Coastal populations of brook trout, Salvelinus fontinalis, in Lac Guilaume-Delisle (Richmond Gulf), Québec. Can. J. Zool. 58:1828-1835.

East P, Magnan P, 1991. Some factors regulating piscivory of brook trout, Salvelinus fontinalis, in lakes of the Laurentian Shield. Can. J. Fish. Aquat. Sci. 48:1735-1743.

Eby LA, Roach WJ, Crowder LB, Stanford JA, 2006. Effects of stocking-up freshwater food webs. TREE 21:576-584.

Elser JJ, Luecke C, Brett MT, Goldman CR, 1995. Effects of food web compensation after manipulation of rainbow trout in an oligotrophic lake. Ecology 76:52-69.

Embody G, Gordon M, 1924. A comparative study of natural and artificial foods of brook trout. Trans. Am. Fish. Soc. 54:185-200.

Ensign WE, Strange RJ, Moore SE, 1990. Summer food limitation reduced brook and rainbow trout biomass in a southern Appalachian stream. Trans. Am. Fish. Soc. 119:894-901.

Farwell M, Fuzzen ML, Bernier NJ, McLaughlin RL, 2014. Individual differences in foraging behavior and cortisol levels in recently emerged brook charr (Salvelinus fontinalis). Behav. Ecol. Sociobiol. 68:781-790.

Farwell M, McLaughlin RL, 2009. Alternative foraging tactics and risk taking in brook charr (Salvelinus fontinalis). Behav. Ecol. 20:913-921.

Fausch KD, 1984. Profitable stream positions for salmonids: relating specific growth rate to net energy gain. Can. J. Zool. 62:441-451.

Fechney LR, 1988. The summer diet of brook trout (Salvelinus fontinalis) in a South Island high-country stream. N. Zeal. J. Mar. Fresh. 22:163-168.

Ferriz RA, Baigún CR, Dominino J, 2010. Distribution patterns and trophic characteristics of salmonids and native species inhabiting high altitude rivers of Pampa de Achala region, Argentina. Neotrop. Ichthyol. 8:851-860.

Flick WA, 1977. Some observations, age, growth, food habits and vulnerability of large brook trout (Salvelinus fontinalis) from four Canadian lakes. Nat. Can. 104:353-359.

Forrester GE, Chace JG, McCarthy W, 1994. Diel and densityrelated changes in food consumption and prey selection by brook charr in a New Hampshire stream. Env. Biol. Fish. 39:301-311.

Frenette JJ, Dodson JJ, 1984. Brook trout (Salvelinus fontinalis) population structure in acidified Lac Tantaré, Quebec. Can. J. Fish. Aquat. Sci. 41:865-877.

García-Berthou E, Alcaraz C, Pou-Rovira Q, Zamora L, Coenders G, Feo C, 2005. Introduction pathways and establishment rates of invasive aquatic species in Europe. Can. J. Fish. Aquat. Sci. 62:453-463.

Gaudreault A, Castonguay M, Fitzgerald GJ, 1982. Répartition des ressources et changements saisonniers de l'alimentation d'ombles de fontaine anadromes, Salvelinus fontinalis. Can. J. Zool. 60:3068-3070.

Gowan C, Fausch KD, 2002. Why do foraging salmonids move during summer? Env. Biol. Fish. 64:139-153.

Grant JW, Noakes DL, 1986. A test of a size-selective predation model with juvenile brook charr, Salvelinus fontinalis. J. Fish Biol. 29:15-23.

Grant JW, Noakes DL 1987. Movers and stayers: foraging tactics of young-of-the-year brook charr, Salvelinus fontinalis. J. Anim. Ecol. 56:1001-1013.

Grant JW, Noakes DL, 1988. Aggressiveness and foraging mode of young-of-the-year brook charr, Salvelinus fontinalis (Pisces, Salmonidae). Behav. Ecol. Sociobiol. 22:435-445.

Grant JW, Noakes DL, Jonas KM, 1989. Spatial distribution of defence and foraging in young-off-the-year Brook Charr, Salvelinus fontinalis. J Anim. Ecol. 58:773-784.

Greeley JR, 1927. Fishes of the Genesee region with annotated list, p. 47-66. In: New York State Department of Conservation (ed.), A biological survey of the Genesee River system. Suppl. 16th Annu. Rep. 1926. New York State Department of Conservation, Albany.

Greeley JR, 1928. Fishes of the Oswego watershed, p. 84-107. A biological survey of the Oswego River system. In: New York State Department of Conservation (ed.), A biological survey of the Genesee River system. Suppl. 17th Annu. Rep. 1927. New York State Department of Conservation, Albany.

Griffith JJ, 1974. Utilization of invertebrate drift by brook trout (Salvelinus fontinalis) and cutthroat trout (Salmo clarki) in small streams in Idaho. Trans. Am. Fish. Soc. 103:440-447. 
Griffiths D, 1980. Foraging costs and relative prey size. Am. Nat. 116:743-752.

Grueber CE, Nakagawa S, Laws RJ, Jamieson IG, 2011. Multimodel inference in ecology and evolution: challenges and solutions. J. Evol. Biol. 24:699-711.

Gunckel SL, 2000. Feeding behavior and diet of native bull trout Salvelinus confluentus and introduced brook trout $S$. fontinalis in two eastern Oregon streams. MS Thesis, Oregon State University.

Gunckel SL, Hemmingsen AR, Li JL, 2002. Effect of bull trout and brook trout interactions on foraging habitat, feeding behavior, and growth. Trans. Am. Fish. Soc. 131:1119-1130.

Harkness WJK, Ricker WE, 1929. A preliminary study of some trout waters of Ontario. Trans. Am. Fish. Soc. 59:256-265.

Hartman KJ, Cox MK, 2008. Refinement and testing of a brook trout bioenergetics model. Trans. Am. Fish. Soc. 137:357-363.

Hartman KJ, Sweka JA, 2001. Development of a bioenergetics model for Appalachian brook trout. Proc. Southeast. Ass. Fish Wild. Agen. 55:38-51.

Helfrich LA, Wolfe JJR, Bromley PT, 1982. Agonistic behavior, social dominance, and food consumption of brook trout and rainbow trout in a laboratory stream. Proc. Annu. Confer. Southeast Assoc. Fish and Wildlife Agencies 36:340-350.

Hildebrand SF, Towers IL, 1927. Food of trout in fish Lake, Utah. Ecology 8:389-397.

Hilderbrand RH, Kershner JL, 2004. Influence of habitat type on food supply, selectivity, and diet overlap of Bonneville cutthroat trout and nonnative brook trout in Beaver Creek, Idaho. N. Am. J. Fish. Manage. 24:33-40.

Hubert WA, Rhodes HA, 1989. Food selection by brook trout in a subalpine stream. Hydrobiologia 178:225-231.

Hyslop EJ, 1980. Stomach contents analysis - a review of methods and their application. J. Fish Biol. 17:411-429.

Johnston C, 1980. Observations on the foods of brook trout (Salvelinus fontinalis) and rainbow trout (Salmo gairdneri) in the Dunk River system, Prince Edward Island. Proc. Nova Scotian Inst. Sci. 30:31-40.

Jonsson B, Jonsson N, 2001. Polymorphism and speciation in Arctic charr. J. Fish Biol. 58:605-638

Juday C, 1907a. Studies on some lakes in the Rocky and Sierra Nevada Mountains. Trans. Wisconsin Acad. Sci. Arts Letters 15:781-793.

Juday C, 1907b. A study of Twin Lakes, Colorado, with especial consideration of the food of the trouts. US Government Printing Office: $32 \mathrm{pp}$.

Juncos R, Beauchamp DA, Vigliano PH, 2013. Modeling prey consumption by native and nonnative piscivorous fishes: implications for competition and impacts on shared prey in an ultraoligotrophic lake in Patagonia. Trans. Am. Fish. Soc.142: 268-281.

Juncos R, Milano D, Macchi PJ, Vigliano PH, 2015. Niche segregation facilitates coexistence between native and introduced fishes in a deep Patagonian lake. Hydrobiologia 747:53-67.

Knapp RA, Matthews KR, Sarnelle O, 2001. Resistance and resilience of alpine lake fauna to fish introductions. Ecol. Monogr. 71:401-421.

Kraus JM, Pomeranz JF, Todd AS, Walters DM, Schmidt TS, Wanty RB, 2016. Aquatic pollution increases use of terrestrial prey subsidies by stream fish. J. Appl. Ecol. 53:44-53.
Lacasse S, Magnan P, 1992. Biotic and abiotic determinants of the diet of brook trout, Salvelinus fontinalis, in lakes of the Laurentian Shield. Can. J. Fish. Aquat. Sci. 49:1001-1009.

Lackey RT, 1969. Food interrelationships of salmon, trout, alewives, and smelt in a Maine lake. Trans. Am. Fish. Soc. 98:641-646.

Lehner P, 1996. Handbook of ethological methods. Cambridge University Press, Cambridge: 694 pp.

Leonard A, 1927. The rate of growth and the food of the horned dace (Semotilus atromaculatus) in Quebec, with some data on the food of the common hiner (Notropis cornutus) and of the brook trout (Salvelinus fontinalis) from the same region. University Library.

Leonard JW, 1941. Observations on the winter feeding habits of eastern brook trout in relation to natural food organisms present. Prog. Fish Cult.t 8:37-37.

Leonard JW, 1942. Some observations on the winter feeding habits of brook trout fingerlings in relation to natural food organisms present. Trans. Am. Fish. Soc. 71:219-227.

Lord RF, 1933. Type of food taken throughout the year by brook trout in a single Vermont stream with special reference to winter feeding. Trans. Am. Fish. Soc. 63:182-197.

Macchi PJ, Cussac VE, Alonso MF, Denegri MA, 1999. Predation relationships between introduced salmonids and the native fish fauna in lakes and reservoirs in northern Patagonia. Ecol. Freshw. Fish 8:227-236.

Macchi PJ, Pascual MA, Vigliano PH, 2007. Differential piscivory of the native Percichthys trucha and exotic salmonids upon the native forage fish Galaxias maculatus in Patagonian Andean lakes. Limnologica 37:76-87.

Magnan P, FitzGerald GJ, 1982. Resource partitioning between brook trout (Salvelinus fontinalis Mitchill) and creek chub (Semotilus atromaculatus Mitchill) in selected oligotrophic lakes of southern Quebec. Can. J. Zool. 60:1612-1617.

Magnan P, FitzGerald GJ, 1984. Mechanisms responsible for the niche shift of brook charr, Salvelinus fontinalis Mitchill, when living sympatrically with creek chub, Semotilus atromaculatus Mitchill. Can. J. Zool. 62:1548-1555.

Magnea U, Sciascia R, Paparella F, Tiberti R, Provenzale A, 2013. A model for high-altitude alpine lake ecosystems and the effect of introduced fish. Ecol. Mod 251:211-220.

McGrath C, Lewis JW 2007. Competition and predation as mechanisms for displacement of greenback cutthroat trout by brook trout. Trans. Am. Fish. Soc. 136:1381-1392.

McLaughlin RL, Grant JW, Kramer DL, 1992. Individual variation and alternative patterns of foraging movements in recently-emerged brook charr (Salvelinus fontinalis). Behaviour 120:286-301.

McLaughlin RL, Grant JWA, Noakes DLG, 2000. Living with failure: the prey capture success of young brook charr in streams. Ecol. Freshw. Fish 9:81-89.

McNicol RE, Noakes DL, 1981. Territories and territorial defense in juvenile brook charr, Salvelinus fontinalis (Pisces: Salmonidae). Can. J. Zool. 59:22-28.

McNicol RE, Scherer E, Murkin EJ, 1985. Quantitative field investigations of feeding and territorial behaviour of youngof-the-year brook charr, Salvelinus fontinalis. Environ. Biol. Fish. 12:219-229.

Metzelaar J, 1929. The food of the trout in Michigan. Trans. Am. Fish. Soc. 59:146-152. 
Milano D, Cussac VE, Macchi PJ, Ruzzante DE, Alonso MF, Vigliano PH, Denegri MA, 2002. Predator associated morphology in Galaxias platei in Patagonian lakes. J. Fish Biol. 61:138-156.

Miller JM, 1974. The food of brook trout Salvelinus fontinalis (Mitchill) fry from different subsections of Lawrence Creek, Wisconsin. Trans. Am. Fish. Soc. 103:130-134.

Miró A, Ventura M, 2013. Historical use, fishing management and lake characteristics explain the presence of non-native trout in Pyrenean lakes: implications for conservation. Biol. Cons. 167:17-24.

Miró A, Ventura M, 2015. Evidence of exotic trout mediated minnow invasion in Pyrenean high mountain lakes. Biol. Invasions 17:791-803.

Mittelbach GG, Persson L, 1998. The ontogeny of piscivory and its ecological consequences. Can. J. Fish. Aquat. Sci. 55:1454-1465.

Mookerji N, Weng Z, Mazumder A, 2004. Food partitioning between coexisting Atlantic salmon and brook trout in the Sainte-Marguerite River ecosystem, Quebec. J. Fish Biol. 64:680-694

Morgulis S, 1918. Studies on the nutrition of fish: experiments on brook trout. Trans. Am. Fish. Soc. 48:34-56.

Morinville GR, 2005. The bioenergetic basis of anadromy in brook trout (Salvelinus fontinalis). $\mathrm{PhD}$ thesis, McGill University Montréal, Québec, Canada.

Morinville GR, Rasmussen JB, 2006. Marine feeding patterns of anadromous brook trout (Salvelinus fontinalis) inhabiting an estuarine river fjord. Can. J. Fish. Aquat. Sci. 63:2011-2027.

Needham JG, 1903. Food of brook trout in Bone Pond. B. NY St. Mus. 68:204-217.

Needham PR, 1928. A quantitative study of the fish food supply in selected areas. New York State.

Needham PR, 1930. Studies on the seasonal food of brook trout. Trans. Am. Fish. Soc. 60:73-88.

Nyman O, 1970. Ecological interaction of brown trout, Salmo trutta L., and brook trout, Salvelinus fontinalis (Mitchill), in a stream. Can. Field Nat. 84:343-350.

O'Brien WJ, 1979. The predator-prey interaction of planktivorous fish and zooplankton: recent research with planktivorous fish and their zooplankton prey shows the evolutionary thrust and parry of the predator-prey relationship. Am. Sci. 67:572-581.

O'Connell MF, 1982. The biology of anadromous Salvelinus fontinalis (Mitchill, 1815) and Salmo trutta Linnaeus, 1758 in river systems flowing into Placentia Bay and St. Mary's Bay, Newfoundland. PhD Thesis, University of Newfoundland.

Ojala JV, 2008. Invertebrate phenology and prey selection of three sympatric species of salmonids; implications for individual fish growth. MS thesis, University of Massachusetts.

Power M, Power G, Caron F, Doucett RR, Guiguer KR, 2002. Growth and dietary niche in Salvelinus alpinus and Salvelinus fontinalis as revealed by stable isotope analysis, p. 7585. In: P. Magnan, C. Audet, H. Glémet, M. Legault, M.A. Rodríguez and E.B. Taylor (eds.), Ecology, behaviour and conservation of the charrs, genus Salvelinus. Springer.

Proulx R, Magnan P, 2004. Contribution of phenotypic plasticity and heredity to the trophic polymorphism of lacustrine brook charr (Salvelinus fontinalis M.). Evol. Ecol. Res. 6:503-522.
Reed EB, Bear G, 1966. Benthic animals and foods eaten by brook trout in Archuleta Creek, Colorado. Hydrobiologia 27:227-237.

Reissig M, Trochine C, Queimaliños C, Balseiro E, Modenutti $\mathrm{B}, 2006$. Impact of fish introduction on planktonic food webs in lakes of the Patagonian Plateau. Biol. Cons. 132:437-447.

Ricker WE, 1930. Feeding habits of speckled trout in Ontario waters. Trans. Am. Fish. Soc. 60:64-72.

Ricker WE, 1932. Studies of speckled trout (Salvelinus fontinalis) in Ontario. University of Toronto Press, Toronto.

Rimsky-Korsakoff V, 1930. The food of certain fishes of the Lake Champlain watershed. New York Conservation Department of Biological Surveys.

Sánchez J, Cobo F, González MA, 2007. [Biología y la alimentación del salvelino, Salvelinus fontinalis (Mitchill, 1814), en cinco lagunas glaciares de la Sierra de Gredos (Ávila, España)].[Article in Spanish]. Nova Acta Científica Compostelana 16:129-144.

Sarnelle O, Knapp RA, 2005. Nutrient recycling by fish versus zooplankton grazing as drivers of the trophic cascade in alpine lakes. Limnol. Oceanogr. 50:2032-2042.

Savini D, Occhipinti-Ambrogi A, Marchini A, Tricarico E, Gherardi F, Olenin S, Gollasch S, 2010. The top 27 animal alien species introduced into Europe for aquaculture and related activities. J. Appl. Ichthyol. 26:1-7.

Schabetsberger R, Luger MS, Drozdowski G, Jagsch A, 2009. Only the small survive: monitoring long-term changes in the zooplankton community of an Alpine lake after fish introduction. Biol. Inv. 11:1335-1345.

Skinner MM, Moore BC, Swanson ME, 2014. Hypolimnetic oxygenation in Twin Lakes, WA. Part II: Feeding ecology of a mixed cold-and warm-water fish community. Lake Reservoir Manag. 30:240-249.

Sibley CK, Rimsky-Korsakoff V, 1931. Food of certain fishes in the (St. Lawrence) watershed, p. 109-120. In: New York State Department of Conservation (ed.), A biological survey of the St. Lawrence Watershed. Suppl. 20th Annu. Rep. New York State Department of Conservation, Albany.

Sirois P, Boisclair D, 1995. The influence of prey biomass on activity and consumption rates of brook trout. J. Fish Biol. 46:787-805.

Sotiropoulos JC, Nislow KH, Ross MR, 2006. Brook trout, Salvelinus fontinalis, microhabitat selection and diet under low summer stream flows. Fish. Manag. Ecol. 13:149-155.

Spares AD, Dadswell MJ, MacMillan J, Madden R, O'Dor RK, Stokesbury MJW, 2014. To fast or feed: an alternative life history for anadromous brook trout Salvelinus fontinalis overwintering within a harbour. J. Fish Biol. 85:621-644.

Strogen JJW, 1979. A comparison of the diet and growth of the trout from the upper Au Sable and upper Manistee rivers, Michigan. Fisheries Research Report, 1867, Michigan Department of Natural Resources, Fisheries Division, Lansing.

Sweka JA, 2003. Aquatic-terrestrial linkages in Appalachian streams: influence of riparian inputs on stream habitat, brook trout populations, and trophic dynamics. West Virginia University Libraries, Morgantown.

Sweka JA, Hartman KJ, 2001a. Fall and winter brook trout prey selection and daily ration. Proc. Annu. Conf. Southeastern Assoc. of Fish and Wildlife Agencies. 
Sweka JA, Cox MK, Hartman KJ, 2004. Gastric evacuation rates of brook trout. Trans. Am. Fish. Soc. 133:204-210.

Sweka JA, Hartman KJ, 2001b. Effects of turbidity on prey consumption and growth in brook trout and implications for bioenergetics modeling. Can. J. Fish. Aquat. Sc. 58:386-393.

Sweka JA, Hartman KJ, 2001c. Influence of turbidity on brook trout reactive distance and foraging success. Trans. Am. Fish. Soc. 130:138-146.

Sweka JA, Hartman KJ, 2008. Contribution of terrestrial invertebrates to yearly brook trout prey consumption and growth. Trans. Am. Fish. Soc. 137:224-235.

Swift MC, 1970. A qualitative and quantitative study of trout food in Castle Lake, California. Calif. Fish Game 56:100-120.

Tebo L, Hassler W, 1963. Food of brook, brown, and rainbow trout from streams in western North Carolina. J. Elisha Mitchell Sci. Soc. 79:447-453.

Thorne DW, 2004. Spatial and seasonal variation in brook trout diet, growth, and consumption in a complex Appalachian watershed. MSc thesis, West Virginia University Libraries, Morgantown.

Tiberti R, Acerbi E, Iacobuzio R, 2014c. Preliminary studies on fish capture techniques in Gran Paradiso alpine lakes: towards an eradication plan. J. Mount. Ecol. 9:61-74.

Tiberti R, Brighenti S, Iacobuzio R, Pasquini G, Rolla M, 2014 b. Behind the impact of introduced trout in high altitude lakes: adult, not juvenile fish are responsible of the selective predation on crustacean zooplankton. J. Limnol. 73:969.

Tiberti R, Iacobuzio R, 2013. Does the fish presence influence the diurnal vertical distribution of zooplankton in high transparency lakes? Hydrobiologia 709:27-39.

Tiberti R, Tartari GA, Marchetto A, 2010. Geomorphology and hydrochemistry of 12 Alpine lakes in the Gran Paradiso National Park, Italy. J. Limnol. 69:242-256.

Tiberti R, von Hardenberg A, 2012. Impact of introduced fish on common frog (Rana temporaria) close to its altitudinal limit in alpine lakes. Amphibia-Reptilia 33:303-307.

Tiberti R, von Hardenberg A, Bogliani G, 2014a. Ecological impact of introduced fish in high altitude lakes: a case of study from the European Alps. Hydrobiologia 724:1-19.

Titcomb JW, Cobb EW, Crowell MF, McCay CM, 1928. The nutritional requirements and growth rates of brook trout. Trans. Am. Fish. Soc. 58:205-231.

Utz RM, Hartman KJ, 2006. Temporal and spatial variation in the energy intake of a brook trout (Salvelinus fontinalis) population in an Appalachian watershed. Can. J. Fish. Aquat. Sc. 63:2675-2686.

Utz RM, Hartman KJ, 2007. Identification of critical prey items to Appalachian brook trout (Salvelinus fontinalis) with emphasis on terrestrial organisms. Hydrobiologia 575:259-270.

Utz RM, Ratcliffe BC, Moore BT, Hartman KJ, 2007. Dispro- portionate relative importance of a terrestrial beetle family (Coleoptera: Scarabaeidae) as a prey source for central Appalachian brook trout. Trans. Am. Fish. Soc. 136:177-184.

Vander Zanden MJ, Chandra S, Park SK, Vadeboncoeur Y, Goldman CR, 2006. Efficiencies of benthic and pelagic trophic pathways in a subalpine lake. Can. J. Fish. Aquat. Sci. 63: 2608-2620

Vander Zanden MJ, Vadeboncoeur Y, 2002. Fishes as integrators of benthic and pelagic food webs in lakes. Ecology 83:21522161.

Walsh G, Morin R, Niman RJ, 1988. Daily rations, diel feeding activity and distribution of age- 0 brook charr, Salvelinus fontinalis, in two subarctic streams. Environ. Biol. Fish. 21:195-205.

Wankowski JWJ, 1979. Morphological limitations, prey size selectivity, and growth response of juvenile Atlantic salmon, Salmo salar. J. Fish Biol. 14:89-100.

Webster JJ, Hartman KJ, 2005. The role of terrestrial invertebrates in allopatric brook trout headwater streams in the central Appalachian mountains. J. Freshwat. Ecol. 20:101-107.

White HC, 1930. Some observations on the eastern brook trout (S. fontinalis) of Prince Edward Island. Trans. Am. Fish. Soc. 60:101-108.

White HC, 1940. Life history of sea-running brook trout (Salvelinus fontinalis) of Moser River, NS. J. Fish. Res. Board Can. 5:176-186.

White HC, 1942. Sea life of the brook trout (Salvelinus fontinalis). J. Fish. Res. Board Can. 5:471-473.

White SL, Gowan C, 2014. Social learning enhances search image acquisition in foraging brook trout. Env. Biol. Fish. 97:523-528.

Williams DD, 1981. The first diets of postemergent brook trout (Salvelinus fontinalis) and Atlantic salmon (Salmo salar) alevins in a Quebec river. Can. J. Fish. Aquat. Sci. 38:765-771.

Williamson CE, Fischer JM, Bollens SM, Overholt EP, Breckenridge JK, 2011. Toward a more comprehensive theory of zooplankton diel vertical migration: integrating ultraviolet radiation and water transparency into the biotic paradigm. Limnol. Oceanogr. 56:1603-1623.

Wilson AD, McLaughlin RL, 2010. Foraging behaviour and brain morphology in recently emerged brook charr, Salvelinus fontinalis. Behav. Ecol. Sociobiol. 64:1905-1914.

Wilson MK, Lowe WH, Nislow KH, 2014. What predicts the use by brook trout (Salvelinus fontinalis) of terrestrial invertebrate subsidies in headwater streams? Freshwater Biol. 59:187-199.

Wiseman J, 1951. A quantitative analysis of foods eaten by eastern brook trout. Wyoming Wildlife 15:12-17.

Wurtsbaugh WA, Brocksen RW, Goldman CR, 1975. Food and distribution of underyearling brook and rainbow trout in Castle Lake, California. Trans. Am. Fish. Soc. 104:88-95. 